This document was prepared in conjunction with work accomplished under Contract No. DE-AC09-96SR18500 with the U. S. Department of Energy.

\title{
DISCLAIMER
}

This report was prepared as an account of work sponsored by an agency of the United States Government. Neither the United States Government nor any agency thereof, nor any of their employees, nor any of their contractors, subcontractors or their employees, makes any warranty, express or implied, or assumes any legal liability or responsibility for the accuracy, completeness, or any third party's use or the results of such use of any information, apparatus, product, or process disclosed, or represents that its use would not infringe privately owned rights. Reference herein to any specific commercial product, process, or service by trade name, trademark, manufacturer, or otherwise, does not necessarily constitute or imply its endorsement, recommendation, or favoring by the United States Government or any agency thereof or its contractors or subcontractors. The views and opinions of authors expressed herein do not necessarily state or reflect those of the United States Government or any agency thereof. 
WSRC-TR-2005-00493

Revision 0

\section{SLUDGE BATCH 4 WITHOUT TANK 4 SIMULANT FLOWSHEET STUDIES: PHASE I SRAT RESULTS}

C.C. Herman

D.R. Best

D.P. Lambert

M.E. Stone

M.F. Williams

November 2005

Immobilization Technology Section Savannah River National Laboratory Aiken, SC 29808

Prepared for the U.S. Department of Energy Under Contract Number DEAC09-96SR18500

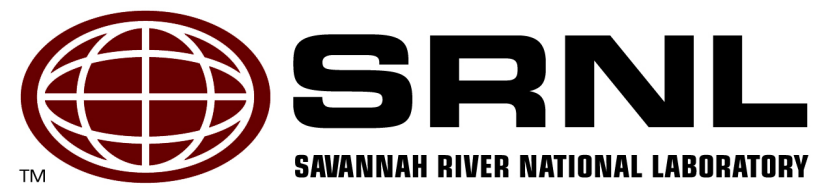




\section{DISCLAIMER}

This report was prepared by Westinghouse Savannah River Company (WSRC) for the United States Department of Energy under Contract No. DE-AC09-96SR18500 and is an account of work performed under that contract. Neither the United States Department of Energy, nor WSRC, nor any of their employees makes any warranty, expressed or implied, or assumes any legal liability or responsibility for the accuracy, completeness, or usefulness, of any information, apparatus, or product or process disclosed herein or represents that its use will not infringe privately owned rights. Reference herein to any specific commercial product, process, or service by trademark, name, manufacturer, or otherwise does not necessarily constitute or imply endorsement, recommendation, or favoring of same by WSRC or by the United States Government or any agency thereof. The views and opinions of the authors expressed herein do not necessarily state or reflect those of the United States Government or any agency thereof.

\section{Printed in the United States of America \\ Prepared For U.S. Department of Energy}


WSRC-TR-2005-00493

Revision 0

Key Words: DWPF, Sludge, SB4

Retention: Permanent

\title{
SLUDGE BATCH 4 WITHOUT TANK 4 SIMULANT FLOWSHEET STUDIES: PHASE I SRAT RESULTS
}

\author{
C.C. Herman \\ D.R. Best \\ D.P. Lambert \\ M.E. Stone \\ M.F. Williams
}

November 2005

Immobilization Technology Section Savannah River National Laboratory Aiken, SC 29808 


\section{REVIEWS AND APPROVALS}

AUTHORS:

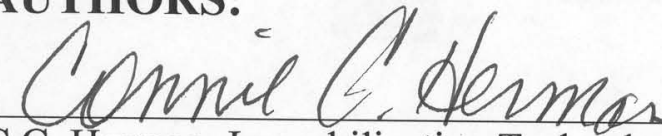

C.C. Herman, Immobilization Technology Section

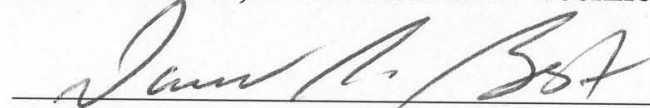

D.R. Best, Immobilization Technology Section

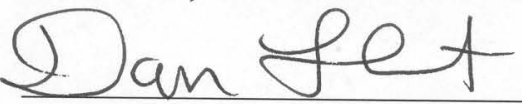

D.P. Lambert, Waste Processing Technology Section MESM

M.E. Stone, Immobilization Technology Section

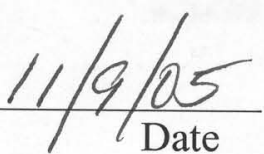

Nit Nilloms

M.F. Williams, Immobilization Technology Section

$11-10-05$

$11-9-05$

Date

$11 / 9 / 0 s$

Date

TECHNICAL REVIEWER:

Lu fareys

$11-9-05$

J.M. Pareizs, Immobilization Technology Section

Date

\section{APPROVERS:}

Rrkduads

R.E. Edwards, Manager, Immobilization Technology Section

$11 / 9 / 05$

Shaven of hans.

S.L. Marra, Manager, Glass Formulation \& Process Development

Date

Tou 2. Clee hoi

J. Z. Occhipinti, Manager,

Process Cognizant Engineering - Waste Solidification Engineering

$11-30-05$

Date

Date

$1 / 10 / 05$ 


\section{EXECUTIVE SUMMARY}

A set of simulant flowsheet runs using co-precipitated Sludge Batch 4 (SB4) simulant has been performed by the Savannah River National Laboratory (SRNL) - Immobilization Technology Section (ITS). This simulant reflected updated composition information from the Closure Business Unit since Tank 4 has been excluded from SB4 and settling issues have occurred in Tank 51. The flowsheet testing is part of the planning and qualification effort that is performed by SRNL for every sludge batch to be processed in the Defense Waste Processing Facility (DWPF). The work was performed to meet the requirements outlined in Technical Task Request (TTR) HLW/DWPF/TTR-04-0031 (Washburn 2004).

A task technical and quality assurance plan was written by Baich (2004) in response to the TTR and provided guidance for the testing. The main objective of this set of tests was to assist in the determination of the SB4 washing endpoint and to bound SB4 processing based on projected compositions. Previous testing (Baich et. al. 2005) addressed compositions for SB4 that included Tank 4 with different washing endpoints and determined an acceptable operating window. However, the changes in composition and planning necessitated another set of flowsheet tests to be performed.

For this set of flowsheet runs, the ITS used sludge simulant fabricated by the ITS Simulant Development program. The target composition was based on a SB4/Tank 51 washing strategy to target a $\sim 1.6 \mathrm{M} \mathrm{Na}$ endpoint. Once SB4 is qualified, it will be transferred to a heel of SB3 in Tank 40 to meet accelerated closure commitments. The simulant reflected blending with a 40" heel of SB3 in Tank 40. This level was selected since it contained the higher concentration of anions to be removed during DWPF processing and a higher concentration of SB4, which less is known about.

Two Sludge Receipt and Adjustment Tank (SRAT) cycles were performed at different acid addition levels. The lower acid test was at $130 \%$ of stoichiometry and was identified as run SB4-19, while the higher acid test was at $170 \%$ of stoichiometry and was identified as run SB4-20. Both runs used the same level of noble metals and mercury, which were the same levels used in earlier SB4 flowsheet testing. Due to the number of samples that were taken and the subsequent small quantity of SRAT product fabricated, a portion of each SRAT product was combined to perform a Slurry Mix Evaporator (SME) cycle with Frit 418 targeting a waste loading of $43 \%$ and a total solids loading of $50 \%$. The main objective of the SME cycle was to determine the rheology of the SME product so the feasibility of pumping the material for melt rate testing could be evaluated. In addition, performing the SME cycle allowed insight to be gained into SME processing for the particular wash endpoint. Portions of the SME product were adjusted with frit and water additions to determine rheology at $35 \%$ waste loading and $45 \%$ total solids to support melt rate testing.

Primary findings from the testing include:

- Nitrite was destroyed to below the DWPF limit in both runs.

- The sludge simulant was very thick at the start of SRAT processing (i.e., yield stress of $\sim 300$ dynes $/ \mathrm{cm}^{2}$ and consistency of $\sim 15$ centipoise). The slurry thinned noticeably during formic acid addition and the yield stress of both SRAT products were much lower than the starting sludge (i.e., $65 \mathrm{dynes} / \mathrm{cm}^{2}$ for SB4-19 and 7.5 dynes $/ \mathrm{cm}^{2}$ for SB4-20). The consistency was only slightly reduced for the two products, with the SB4-20 product being roughly half of the starting sludge.

- A combination of four waste loadings and total solids were targeted to support the melt rate testing. The SME product was processed to target $43 \%$ waste loading and $50 \%$ total solids. This product had the highest yield stress $\left(\sim 1200\right.$ dynes $\left./ \mathrm{cm}^{2}\right)$ and consistency ( 140 centipoise), while the SME product at $35 \%$ waste loading and $45 \%$ total solids had the lowest yield stress $\left(\sim 320\right.$ dynes $\left./ \mathrm{cm}^{2}\right)$ and consistency $(\sim 59$ centipoise). The materials were considered too thick for slurry fed melt rate furnace testing and are also higher than what has been seen for previous sludge batches (both simulant and radioactive feeds). 
- A small amount of hydrogen was detected in the lower acid run (peak generation of $0.058 \mathrm{lbs} / \mathrm{hr}$ on a DWPF scale), while the higher acid run had a peak of $0.301 \mathrm{lbs} / \mathrm{hr}$ on a DWPF scale. The timing of the peaks appeared to correspond with complete nitrite destruction. During the SME cycle, the combined SRAT product produced a peak hydrogen generation rate of $0.088 \mathrm{lbs} / \mathrm{hr}$ on a DWPF scale near the end of the SME cycle. Peaks of hydrogen also occurred upon the return to boiling after frit addition but at slightly lower rates. This behavior in the SME cycle was also seen in SB3 simulant testing.

- The peak $\mathrm{CO}_{2}$ concentrations were seen during acid addition. As in previous investigations, the peaks during acid addition were attributed to carbonate and nitrite destruction. The peak was $21.4 \%$ and occurred during the higher acid run (SB4-20). Minimal $\mathrm{CO}_{2}$ was seen in the SME with the peaks corresponding to the time where boiling was initiated. Generally speaking, the $\mathrm{CO}_{2}$ generation mirrored the hydrogen and $\mathrm{N}_{2} \mathrm{O}$ generation.

- The peak $\mathrm{N}_{2} \mathrm{O}$ generation rate was $2.0 \%$ during both runs, and peak $\mathrm{NO}$ generation rate was $3.99 \%$ in the high acid run (SB4-20). Most of the $\mathrm{N}_{2} \mathrm{O}$ and $\mathrm{NO}$ generated occurred during acid addition. In the SME, $\mathrm{N}_{2} \mathrm{O}$ peak generation rate was $0.53 \%$ and occurred at the same time as the hydrogen and carbon dioxide peaks. No nitric oxide was detected in the SME.

- A range of 23.24 to $28.56 \%$ of the added formate was destroyed or removed during SRAT processing. Nitrite to nitrate conversion ranged from 22.32 to $23.66 \%$. SME processing resulted in an additional formate loss of $10.2 \%$ and a nitrate loss of $7.49 \%$.

- Based on SRAT product supernate analyses, SRAT processing greatly increased the solubility of Ca, $\mathrm{Mg}$, and Mn (which would be expected based on the anticipated SRAT reactions with formate and nitrate). In the higher acid run (SB4-20), $\mathrm{Cu}, \mathrm{Fe}, \mathrm{Ni}$, and $\mathrm{Ru}$ showed increased solubility. These elements were added as soluble species, but became insoluble during sludge fabrication. As increased levels of acid were added and $\mathrm{pH}$ remained low, they reacted to form more soluble species.

- Based on the simulants used, no foaming or processing issues such as air entrainment were identified. Problems with mixing did occur because of the thickness of the sludge, but acid addition greatly decreased the consistency during processing, which in turn helped with mixing.

- Mercury was reduced in both SRAT runs below the DWPF target of $0.45 \mathrm{wt} \%$ in the solids, with slightly more mercury reduced in the higher acid run.

Compared to the previously tested SB4 composition with Tank 4, fabricated using the traditional partial precipitation fabrication (i.e., most of transition metals co-precipitated but not $\mathrm{Al}$ ), and at two different washing scenarios:

- The pHs of the SRAT products for this testing were more consistent with previous behavior associated with acid addition. The higher acid run had a lower $\mathrm{pH}$, which would be expected but was not the case in some of the previous SB4 runs.

- As with historical flowsheet studies, hydrogen appeared to be generated after nitrite had been destroyed. In the earlier SB4 testing, there was evidence of hydrogen generation before the nitrite was completely destroyed.

Flowsheet testing will continue once plans for SB4 preparation are better finalized. This information should be available after settling testing is completed on the Tank 51 samples, since the data will provide information on settling ability so the final solids and wash endpoint can be determined. The flowsheet testing will include updated $\mathrm{Hg}$ concentrations to ensure that acceptable $\mathrm{Hg}$ reduction occurs. Based on the Tank $51 \mathrm{Hg}$ concentration, the $1 \mathrm{wt} \% \mathrm{Hg}$ level tested in this set of runs still appears to be lower than what SB4 will be during DWPF processing. This lower $\mathrm{Hg}$ level should produce a conservative hydrogen production number. The noble metals levels will also be adjusted as new compositional information is obtained and as the ITS Hydrogen Program provides information on recommended evaluation strategies. This testing will commence when the ITS Simulant Development program defines a recommended sludge fabrication process and representative sludge is fabricated. Although problems with rheology were 
WSRC-TR-2005-00493

Revision 0

encountered, the washing endpoint or an equivalent endpoint with similar concentrations of acid calculation inputs (e.g., nitrite, hydroxide, and carbonate) appears to be feasible from a chemical processing standpoint. 
TABLE OF CONTENTS

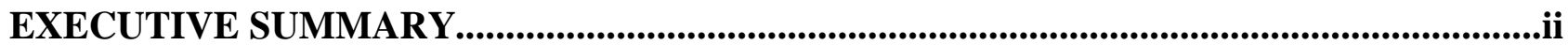

LIST OF FIGURES.........................................................................................................................

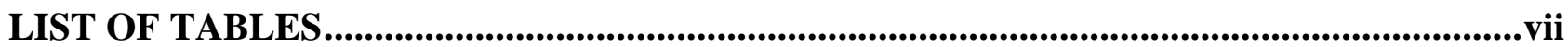

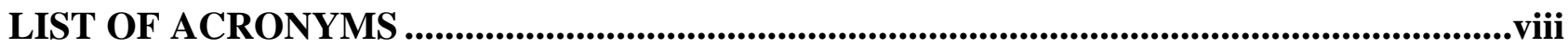

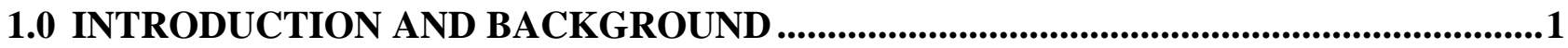

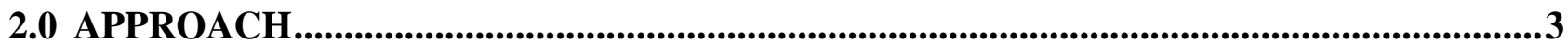

$2.1 \quad$ Sludge Simulant Composition and Fabrication...................................................................... 3

2.2 Procedures and Equipment Used in Testing ………...............................................................

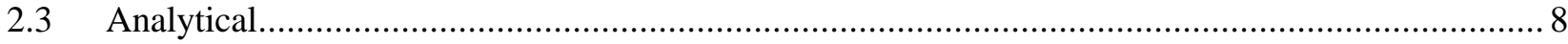

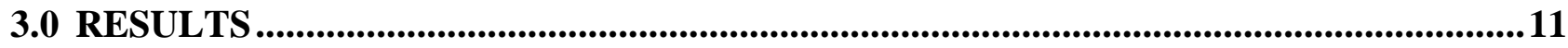

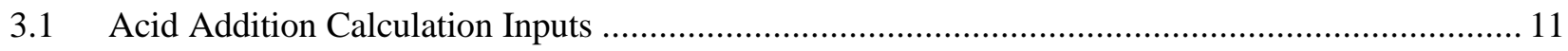

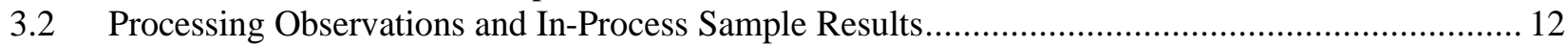

3.3 Generated Off Gas Data and Condensate Analyses ................................................................ 15

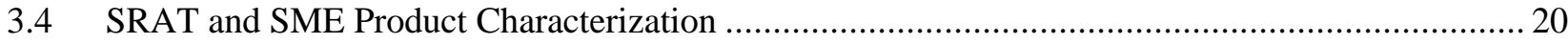

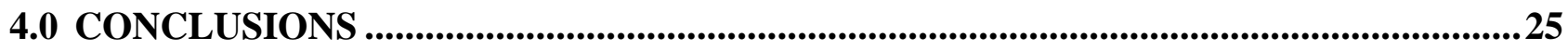

5.0 RECOMMENDATIONS/PATH FORWARD ….............................................................27

6.0 REFERENCES....................................................................................................................29

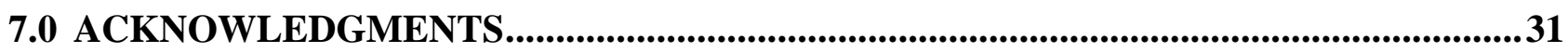

ATTACHMENT A. RUN PARAMETERS AND SUPPORTING DATA.................................33 


\section{LIST OF FIGURES}

Figure 2-1: Schematic of SRAT Equipment Set-Up ...................................................... 7

Figure 3-1: Supernate Data Comparison - Higher Concentrations....................................... 14

Figure 3-2: Supernate Data Comparison - Lower Concentrations ......................................... 15

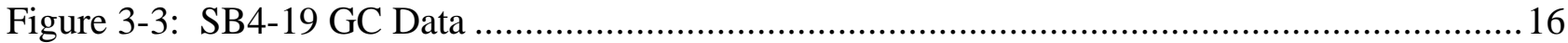

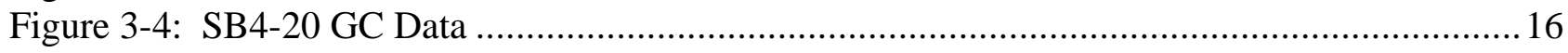

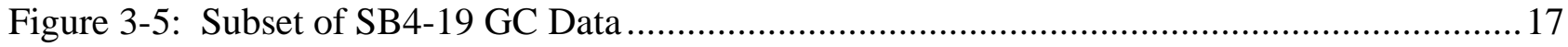

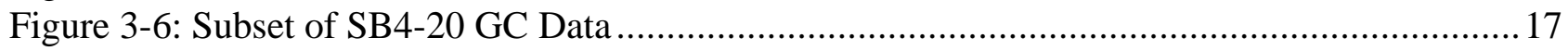

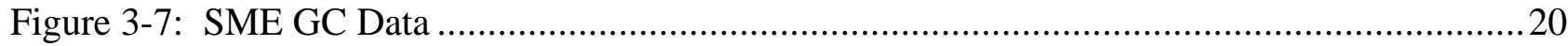

Figure A - 1: Flow Curves for SRAT Products................................................................ 37

Figure A - 2: Flow Curves for SME Product at 43\% Waste Loading ........................................38

Figure A - 3: Flow Curves for SME Product at 35\% Waste Loading ........................................38 


\section{LIST OF TABLES}

Table 2-1: Target and Analyzed Composition of SB4 Simulant without Tank 4........................4

Table 2-2: Supernate Chemistry Targets for Tested Wash Scenario ............................................5

Table 2-3: Analytical Results for Simulant Anions ....................................................

Table 2-4: Additional Property Data for SB4 Simulants..................................................

Table 2-5: Target Levels of Noble Metals Used in Testing...................................................6

Table 3-1: Pre-Run Measured Inputs and Assumptions for Acid Calculation ............................... 11

Table 3-2: Supernate Anion Data for In-Process Samples (mg/kg) ...................................... 13

Table 3-3: Elemental Supernate Data from In-Process Samples (mg/L) .................................. 14

Table 3-4: Peak Gas Concentrations and Hydrogen Generation Rates....................................... 18

Table 3-5: Condensate Sample Results (mg/L) .................................................................. 19

Table 3-6: SRAT and SME Product Anion Concentrations $(\mathrm{mg} / \mathrm{kg})$......................................20

Table 3-7: Conversion of Nitrite to Nitrate, Destruction of Nitrate and Formate..........................21

Table 3-8: Product Results (Calcined Solids Wt\% Basis) ................................................22

Table 3-9: Solubility of Elements in the SRAT Product Supernate.........................................22

Table 3-10: Additional Property Data on SRAT and SME Products.....................................22

Table 3-11: Rheological Data on SRAT Products and SME Samples .....................................24

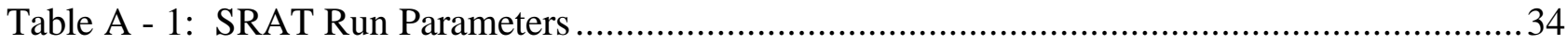

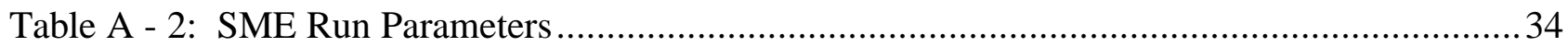

Table A - 3: Mass Balance for Run SB4-19 ................................................................ 35

Table A - 4: Mass Balance for Run SB4-20 ................................................................. 36

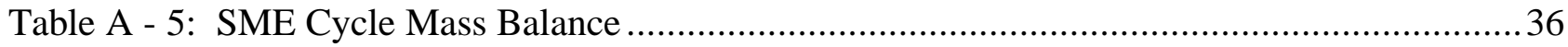




\section{LIST OF ACRONYMS}

ACTL

ASP

CBU

CV

DWPF

FAVC

GC

HLW

IC

ICP-AES

ITS

ITS-AL

MCU

MWWT

PIT

QA

SB3

SB4

SME

SMECT

SMRF

SRAT

SRNL

TIC

TTR
Aiken County Technologies Laboratory

Analytical Study Plan

Closure Business Unit

Cold Vapor

Defense Waste Processing Facility

Formic Acid Vent Condenser

Gas Chromatograph

High Level Waste

Ion Chromatography

Inductively Coupled Plasma - Atomic Emission Spectroscopy

Immobilization Technology Section

Immobilization Technology Section - Analytical Laboratory

Modular Caustic Side Solvent Extraction Unit

Mercury Water Wash Tank

Planning Integration \& Technology

Quality Assurance

Sludge Batch 3

Sludge Batch 4

Slurry Mix Evaporator

Slurry Mix Evaporator Condensate Tank

Slurry-Fed Melt Rate Furnace

Sludge Receipt and Adjustment Tank

Savannah River National Laboratory

Total Inorganic Carbon

Technical Task Request 


\subsection{INTRODUCTION AND BACKGROUND}

The Immobilization Technology Section (ITS) is working with Waste Solidification Engineering and the Planning Integration \& Technology (PIT) department of the Closure Business Unit (CBU) to support the preparation and qualification of Sludge Batch 4 (SB4). SB4 is the next sludge batch to be processed by the Defense Waste Processing Facility (DWPF) with a current need date in early fiscal year 2007. Originally, SB4 was to include Tank 4 and the initial flowsheet testing included the contents of Tank 4 in the projected composition. However, problems with a hard salt layer were encountered when attempts were made to put the slurry pumps in Tank 4. Due to this problem, CBU decided to not include Tank 4 in SB4 so the readiness date could be met.

SB4, as currently projected, will consist of the approximately seven inch heel of Sludge Batch 3 (SB3) in Tank 51, Tank 11, the Tank 7 heel, Tank 5, and Tank 6. As with SB3, plutonium and neptunium solutions from $\mathrm{F}$ and $\mathrm{H}$-Canyons may also be added. In addition to the elemental composition change, settling problems have also been encountered with SB4 in Tank 51 (the DWPF sludge preparation tank). Thus far, only the approximately seven inch heel of SB3, which remained in Tank 51 after the transfer of SB3 to Tank 40 (the current DWPF feed tank), and the contents of Tank 11 are contained in Tank 51. The slower settling currently being experienced in Tank 51 may inhibit SB4 from being washed to a low Na and anion molarity. To help the CBU with determining a suitable washing endpoint, the PIT group provided ITS with six bounding compositions that considered the SB4 target wash endpoint $(\sim 1 \mathrm{M}$ or $\sim 1.6 \mathrm{M} \mathrm{Na})$ and different blending points with SB3 in Tank 40 (127" or 40" SB3 heel remaining). The elemental compositions were documented in CBU-PIT-2005-00134 (Elder 2005a) and CBU-PIT-2005-00176 (Elder 2005b). The corresponding supernate compositions were provided by J.M. Gillam ${ }^{1}$.

ITS decided to test the CBU defined case where SB4 is washed to 1.6M Na and then blended with a 40" SB3 heel in Tank 40. This case has the highest concentration of anions that have to be removed during Sludge Receipt and Adjustment Tank (SRAT) processing in the DWPF. Therefore, it should be the most difficult of the cases to process and would give the most conservative operating window. The objective of this set of flowsheet tests was to determine the acid addition window for this particular scenario and to determine if the resulting Slurry Mix Evaporator (SME) product could be processed in the slurry fed melt rate furnace (SMRF).

The flowsheet work to support qualification of SB4 is being performed to meet Technical Task Request (TTR) HLW/DWPF/TTR-2004-0031 (Washburn 2004). The flowsheet runs provide an evaluation of potential chemical processing issues, quantification of the potential hydrogen generation rates, and estimation of the required acid stoichiometry for the sludge. A Task Technical \& Quality Assurance Plan (Baich 2004) was issued outlining the activities and controls necessary to meet the objectives and requirements of the TTR. The studies documented in this report, as well as the flowsheet testing previously performed and documented with the SB4 compositions containing Tank 4 (see Baich et al. 2005), are considered as part of Phase I testing. In the task plan, the stated goal of Phase I testing was to perform tests to assist in the determination of the SB4 washing endpoint and to bound SB4 processing based on projected compositions. The second phase, Phase II, will commence once actual compositional information is available on the contents of SB4 and will be the flowsheet tests to define the processing strategy for the Shielded Cells run with the qualification sample (Shielded Cells run will be performed under a separate TTR).

\footnotetext{
${ }^{1}$ E-mail communication from J.M. Gillam dated 6/23/05 containing four excel spreadsheets entitled SB4_062305_ 1.6M_11-6-06xfer, SB4_062305_1.6M_runto40in, SB4_062305_1M_11-6-06xfer, and SB4_062305_1M_runto40in.
} 
The following TTR requirements were addressed in this testing:

B The effect of bounding concentrations of nitrite, nitrate, and sulfate to help determine the nominal SB4 washing endpoint.

B The hydrogen and nitrous oxide generation rates for SB4 simulant with varying quantities of acid.

B The acid quantities and processing times required for mercury removal and nitrite destruction for sludge only processing.

B The impact of SB4 levels of constituents such as manganese, nickel, mercury, and aluminum on DWPF processing (i.e., acid addition strategy, hydrogen generation, rheology, etc.).

These requirements, as well as the remaining objectives in the TTR, will continue to be addressed as part of the continued SB4 simulant flowsheet development testing. 


\subsection{APPROACH}

This section describes the approach that was used to perform this phase of testing and is divided into three subsections. Section 2.1 describes the sludge simulant composition and provides a brief overview of the sludge fabrication process. Section 2.2 describes the procedures and equipment utilized to perform the flowsheet testing. Finally, Section 2.3 describes the analytical methods and procedures that were used to characterize the SRAT samples, SRAT products, and SME product.

\subsection{Sludge Simulant Composition and Fabrication}

With the decision to not include Tank 4 in SB4, new simulants were needed to test the revised compositions in flowsheet testing. Since the original SB4 simulant was very thin, settled rapidly, and also appeared to have different processing chemistry than previous simulants (Baich et al. 2005), a new method for simulant fabrication was necessary. The ITS Simulant Development program recommended a sludge fabrication technique, which included co-precipitation of most of the major elements in the sludge and the use of the SpinTek rotary filter for washing and concentration. The methods used for sludge fabrication, the target recipe, and characterization were documented by Herman, Poirier, and Stone (2005).

The target composition provided by Elder (2005b) for the case where SB4 is washed to $1.6 \mathrm{M} \mathrm{Na}$ and blended with a 40" heel of SB3 is given in Table 2-1. The analyzed composition and the nominal composition of the SB4 Baseline scenario with Tank 4 from earlier testing (Baich et al. 2005) are also provided in Table 2-1.

No uranium was added to the simulant. The recipe was not adjusted for the lack of uranium, but instead the ratios to iron were held constant. Therefore, the calcined elementals will not match exactly, but the ratios to iron should be similar for the target and actual feed. Some differences from the target were noted. The major elements were within $10 \%$ of the target ratios, with the exception of calcium and nickel. Calcium was about $33 \%$ higher than targeted, while nickel was about $33 \%$ of the target. Potassium and lead were significantly lower than targeted. Since this testing was completed, a review of the sludge fabrication worksheet indicated an error in the nickel and lead calculation. Therefore, both of these elements were low because the target recipe was also low. For calcium and potassium, both are soluble during fabrication and were likely removed during washing and preparation. Although some of these elements participate in chemical reactions during SRAT processing, they are not inputs to the acid addition calculation so they would not affect the amount of acid to be added in this study. They may also impact the feed rheology and the melt rate, but, thus far, have not been shown to be of more importance than the acid calculation inputs for flowsheet testing. Therefore, the differences were considered acceptable for the flowsheet testing.

Compared to the previous SB4 compositions with Tank 4, the major elements also showed some significant differences. Aluminum and sodium were significantly higher in the new sludge simulant, while iron, magnesium, manganese, and nickel were significantly lower. Tank 4 contains a Purex type feed and had an appreciable solids mass, so excluding the tank from SB4 resulted in changes to the major sludge elements' concentrations. Some of the sodium difference can be explained by the different washing scenarios targeted. Of these elements, manganese is known to have an impact on SRAT processing, as one of the goals of the SRAT is to reduce manganese so it is an input to the acid calculation. The lower manganese value without Tank 4 would result in fewer moles of acid being added per liter of slurry. Iron and nickel are also redox active species, but at lower concentrations the impacts would appear to be lessened. 
Table 2-1: Target and Analyzed Composition of SB4 Simulant without Tank 4

\begin{tabular}{||c|c|c|c|c|c||}
\hline Element & $\begin{array}{c}\text { Target } \\
\text { Elemental } \\
\text { (wt\% in } \\
\text { calcined solids) }\end{array}$ & $\begin{array}{c}\text { Target Ratio } \\
\text { to Fe }\end{array}$ & $\begin{array}{c}\text { Analyzed } \\
\text { Simulant (wt\% } \\
\text { in calcined } \\
\text { solids) }\end{array}$ & $\begin{array}{c}\text { Previous SB4 } \\
\text { Simulant } \\
\text { Ratio to Fe } \\
\text { Composition with } \\
\text { Tank 4 (wt\% in } \\
\text { calcined solids) }\end{array}$ \\
\hline $\mathbf{A l}$ & 15.63 & 1.057 & 18.0 & 1.13 & 14.4 \\
\hline $\mathbf{B a}$ & 0.13 & 0.009 & 0.140 & 0.009 & 0.179 \\
\hline $\mathbf{C a}$ & 1.36 & 0.092 & 1.94 & 0.121 & 2.02 \\
\hline $\mathbf{C r}$ & 0.17 & 0.011 & 0.034 & 0.002 & 0.163 \\
\hline $\mathbf{C u}$ & 0.06 & 0.004 & 0.054 & 0.003 & 0.079 \\
\hline $\mathbf{F e}$ & 14.79 & 1 & 16.0 & 1 & 22.9 \\
\hline $\mathbf{K}$ & 1.41 & 0.095 & 0.112 & 0.007 & 0.873 \\
\hline $\mathbf{L a}$ & 0.07 & 0.005 & $\mathrm{NM}$ & $\mathrm{NM}$ & N/A \\
\hline $\mathbf{M g}$ & 0.64 & 0.043 & 0.675 & 0.042 & 1.07 \\
\hline $\mathbf{M n}$ & 3.68 & 0.249 & 3.93 & 0.246 & 5.95 \\
\hline $\mathbf{N a}$ & 17.31 & 1.171 & 19.4 & 1.21 & 12.2 \\
\hline $\mathbf{N i}$ & 2.71 & 0.183 & 1.08 & 0.067 & 3.29 \\
\hline $\mathbf{P b}$ & 0.18 & 0.012 & 0.01 & 0.001 & 0.017 \\
\hline $\mathbf{S}$ & 0.34 & 0.023 & 0.417 & 0.026 & 0.295 \\
\hline $\mathbf{S i}$ & 1.27 & 0.086 & 1.27 & 0.079 & 1.46 \\
\hline $\mathbf{T i}$ & 0.01 & 0.001 & 0.029 & 0.002 & 0.022 \\
\hline $\mathbf{U}$ & 5.95 & 0.402 & $\mathrm{~N} / \mathrm{A}$ & $\mathrm{N} / \mathrm{A}$ & N/A \\
\hline $\mathbf{Z n}$ & 0.09 & 0.006 & 0.245 & 0.015 & 0.125 \\
\hline $\mathbf{Z r}$ & 0.20 & 0.014 & $<0.010$ & $<0.001$ & 0.276 \\
\hline $\mathbf{N} / \mathrm{A}$ & & & & & \\
\hline
\end{tabular}

N/A - Indicates that the element was not added., NM - indicates that the element was not analyzed.

The target supernate chemistry for the simulant is given in Table 2-2. The anion characterization results for the simulant are given in Table 2-3, along with the anion data from the previous SB4 simulant containing Tank 4. The other property data is provided in Table 2-4 with corresponding data from SB4 simulant with Tank 4. 
Table 2-2: Supernate Chemistry Targets for Tested Wash Scenario

\begin{tabular}{|c|c|}
\hline Parameter & Target Value \\
\hline Density (kg/L) & 1.0585 \\
\hline $\mathrm{Na}^{+}(\mathrm{M})$ & 1.3363 \\
\hline $\mathrm{NO}_{2}^{-}(\mathrm{M})$ & 0.5073 \\
\hline $\mathrm{NO}_{3}^{-}(\mathrm{M})$ & 0.2445 \\
\hline $\mathrm{OH}^{-}(\mathrm{M})$ & 0.3369 \\
\hline $\mathrm{Cl}^{-}(\mathrm{M})$ & 0.0013 \\
\hline $\mathrm{SO}_{4}^{2-}(\mathrm{M})$ & 0.0208 \\
\hline $\mathbf{F}^{-}(\mathbf{M})$ & 0.0019 \\
\hline $\mathrm{CO}_{3}^{2-}(\mathrm{M})$ & 0.0763 \\
\hline $\mathrm{AlO}_{2}^{-2}(\mathrm{M})$ & 0.0598 \\
\hline $\mathrm{C}_{2} \mathrm{O}_{4}^{-2}(\mathrm{M})$ & 0.0033 \\
\hline $\mathrm{PO}_{4}^{-3}(\mathrm{M})$ & 0.0012 \\
\hline $\mathbf{K}^{+}(\mathbf{M})$ & 0.0034 \\
\hline Insoluble Solids (wt\%) & 14.90 \\
\hline Total Solids (wt\%) & 21.82 \\
\hline
\end{tabular}

Table 2-3: Analytical Results for Simulant Anions

\begin{tabular}{||c|c|c|c||}
\hline Anion & $\begin{array}{c}\text { SB4 Simulant } \\
\text { without Tank 4 } \\
(\mathbf{m g} / \text { kg slurry) }\end{array}$ & $\begin{array}{c}\text { SB4 Simulant } \\
\text { without Tank 4 } \\
\text { (supernate } \\
\text { molarity) }\end{array}$ & $\begin{array}{c}\text { Previous SB4 } \\
\text { Composition with } \\
\text { Tank 4 (mg/kg } \\
\text { slurry) }\end{array}$ \\
\hline $\mathbf{N O}_{2}{ }^{-}$ & 20200 & 0.516 & 17200 \\
\hline $\mathbf{N O}_{3}{ }^{-}$ & 13700 & 0.259 & 11850 \\
\hline $\mathbf{C l}^{-}$ & $<100$ & $<0.003$ & 328 \\
\hline $\mathbf{S O}_{\mathbf{4}}{ }^{2-}$ & 1590 & 0.019 & 1370 \\
\hline $\mathbf{C}_{\mathbf{2}} \mathbf{O}_{\mathbf{4}}{ }^{2-}$ & $<100$ & 0.001 & 773 \\
\hline
\end{tabular}

Table 2-4: Additional Property Data for SB4 Simulants

\begin{tabular}{||c|c|c||}
\hline Sludge Property & $\begin{array}{c}\text { SB4 Simulant } \\
\text { without Tank 4 }\end{array}$ & $\begin{array}{c}\text { Previous SB4 } \\
\text { Composition with } \\
\text { Tank 4 }\end{array}$ \\
\hline Total Solids (wt\%) & 17.8 & 22.95 \\
\hline Insoluble Solids (wt\%) & 10.6 & 17.3 \\
\hline Soluble Solids (wt\%) & 7.23 & 5.65 \\
\hline Calcined Solids (wt\%) & 12.3 & 16.5 \\
\hline Slurry Density (g/ml) & 1.15 & 1.18 \\
\hline $\mathbf{p H}$ & 12.5 & 12.5 \\
\hline TIC (mg/kg) & 1048 & 1100 \\
\hline Base Equivalents at pH 7 (Eq/L) & 0.562 & 0.405 \\
\hline
\end{tabular}


The analysis of the anions indicates that the targets were met. Oxalate was slightly lower than the target, but is present at a small enough concentration that it is not expected to alter the SRAT chemistry. The new simulant contains slightly higher quantities of salt species due to less washing than the previously tested SB4 simulant. The new washing scenario is actually closer to the "One-Less Wash" scenario investigated in the earlier SB4 testing (Baich et al. 2005).

Due to the thickness of the sludge simulant, the target total and insoluble solids could not be met during fabrication. However, the soluble solids were close to the target, providing further indication that the supernate was close to the target. The slurry density for the new sludge was lower than the previous composition, which would be expected with the lower solids levels. The total inorganic carbon and slurry $\mathrm{pH}$ were consistent with the previous SB4 simulant, while the base equivalents were higher for the current SB4 composition. The higher base equivalents would be expected given the higher hydroxide concentration detected in the Tank 11 samples that have been incorporated in the SB4 projections.

The projections did not include the levels of mercury and noble metals, which are necessary for flowsheet testing since they both have an impact on processing. Projections for the mercury concentration in SB4 indicate that the concentration might be fairly high compared to previous sludge batches. Analysis of the second sample from Tank 11 by Bannochie and Fellinger (2004) indicated that mercury could be as high as $1 \mathrm{wt} \%$ based on a dried solids basis. Preliminary analyses of Tank 51 samples also indicated mercury concentrations $>1 \mathrm{wt} \%^{2}$. Therefore, the $1 \mathrm{wt} \%$ value that was used in earlier flowsheet testing runs was also used in this set since it still appeared to be conservative for hydrogen generation. No additional information was available on noble metals at the time of testing, so the levels used in the first set of flowsheet testing were also used in this set. The noble metals levels were selected from an evaluation performed by Bibler (2005) of the projected levels of La-139 in the earlier SB4 provided compositions. The maximum potential concentration was selected to conservatively bound the acid addition window. Based on the La concentrations provided with the elemental compositions from Elder (2005a and 2005b), the noble metals level should still be conservative for defining the acid addition window. Noble metals and mercury were not precipitated or incorporated in the sludge simulant fabrication process. Instead, they were added to the sludge in the SRAT vessel, which is the typical SRAT protocol due to the very low concentrations. Table 2-5 shows the targeted levels of noble metals. The sludges were not re-analyzed after the noble metals and mercury were added since they have a minimal impact on the overall composition.

Table 2-5: Target Levels of Noble Metals Used in Testing

\begin{tabular}{|c|c|}
\hline Noble Metal & Wt\% in Total Solids \\
\hline $\mathbf{A g}$ & 0.00024 \\
\hline $\mathbf{P d}$ & 0.0120 \\
\hline $\mathbf{R h}$ & 0.0220 \\
\hline $\mathbf{R u}$ & 0.0810 \\
\hline
\end{tabular}

The rheology of the simulant was measured as part of the sludge characterization. The consistency of the feed was $\sim 15$ centipoise and the yield stress was $\sim 300$ dynes $/ \mathrm{cm}^{2}$.

\footnotetext{
${ }^{2}$ Communication with T.L. Fellinger indicated a high Hg concentration. Results will be documented in the Tank 51 sludge characterization report.
} 


\subsection{Procedures and Equipment Used in Testing}

The testing was performed at the Aiken County Technologies Laboratory (ACTL) using the four-liter kettle setup. The SRAT rigs were assembled following the guidelines of SRNL-ITS-2005-00129 (Herman 2005a). The intent of the equipment is to functionally replicate the DWPF processing vessels. The 4-liter glass kettle is used to replicate both the SRAT and the SME, and it is connected to the SRAT Condenser, the Mercury Water Wash Tank (MWWT), and the Formic Acid Vent Condenser (FAVC). The Slurry Mix Evaporator Condensate Tank (SMECT) is represented by a sampling bottle that is used to remove condensate through the MWWT. For the purposes of this paper, the condensers and wash tank are referred to as the offgas components. A sketch of the experimental setup is given as Figure 2-1.

Figure 2-1: Schematic of SRAT Equipment Set-Up

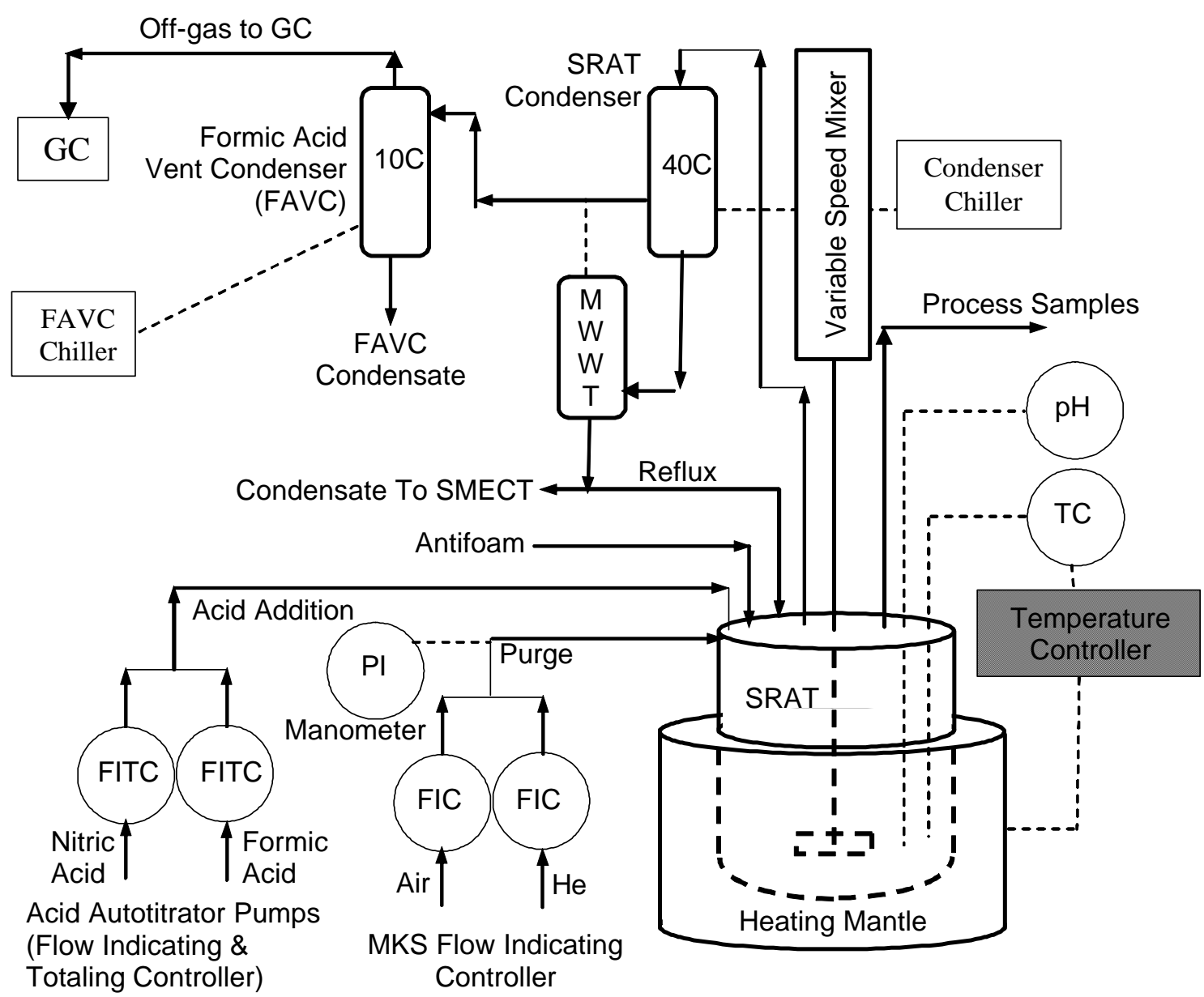

SRAT and SME processing parameters are summarized in Table A - 1 of Attachment A. Each test followed the run plans written for each run (Herman 2005b, Herman 2005c, and Stone 2005a). The SME product adjustments were performed to the guidance of SRNL-ITS-2005-00218 (Stone 2005b). The flowsheet runs were performed using the guidance of Procedure ITS-0094 ("Laboratory Scale Chemical Process Cell Simulations") of Manual L29. Offgas hydrogen, oxygen, nitrogen, nitrous oxide, nitric oxide, carbon monoxide, and carbon dioxide concentrations were measured during the experiments using in-line instrumentation. Helium was introduced at a concentration of $0.5 \%$ of the total air purge as an inert tracer gas so that total amounts of generated gas and peak generation rates could be calculated. Measurement of the 
$\mathrm{pH}$ during the SRAT cycles did not occur due to the problems with the thick sludge. The $\mathrm{pH}$ probe was causing a stagnant zone and was, therefore, removed before processing was initiated. However, the SRAT product was much thinner, and the $\mathrm{pH}$ probe was used during the SME cycle. During the runs, the kettle was monitored to observe reactions that were occurring to include foaming, air entrainment, rheology changes, loss of heat transfer capabilities, and offgas carryover. Observations were recorded in laboratory notebooks WSRC-NB-2005-00055 and WSRC-NB-2005-00085 and are discussed in Section 3.0.

Concentrated nitric acid (50-wt\%) and formic acid (90-wt $\%)$ were used to acidify the sludge and perform neutralization and reduction reactions during processing. The amounts of acid to add for each run were determined using the existing DWPF acid addition equation. The split of the acid was determined using the redox equation currently being used in DWPF processing (Jantzen et al. 2003). The redox target $\left(\mathrm{Fe}^{2+} / \bullet \mathrm{Fe}\right)$ was 0.2 . To account for the reactions and anion destructions that occur during processing, assumptions about nitrite destruction, nitrite to nitrate conversion, and formate destruction were made for each run. The values used for each run are provided in Section 3.0.

To prevent foaming during processing, 200 ppm IIT 747 antifoam was added during heat-up at $40^{\circ} \mathrm{C}$ and 500 ppm was added at the completion of acid addition. The addition strategy was conservative relative to the current DWPF addition strategy to increase sensitivity to foaming issues, and no recommendations on changes to the antifoam addition strategy will be made based on this testing. SRAT processing included the dewater time in boiling plus an additional 12 hours of reflux to simulate DWPF processing conditions. SME processing did not include the addition of canister dewaters. The frit addition was split into two equal portions. The frit was added with water and formic acid at DWPF prototypical conditions. Concentration was performed after each frit addition and then heat was removed to allow for the next frit addition A final concentration was performed at the end of the run to meet the target total solids.

One of the goals of the SME testing was to determine the feasibility of feeding the product to the slurry fed melt rate furnace at two different waste loadings and at two different total solids loadings for a total of four different melter feeds. Therefore, the higher waste loading (i.e., $43 \mathrm{wt} \%$ ) and total solids (i.e., $50 \mathrm{wt} \%$ ) were targeted in the SME so that adjustments could be made to the SME product to meet the lower waste loading and total solids loadings. At the completion of the SME cycle, the SME product was adjusted through frit and water additions to allow rheology and pumping testing at both 35 and $43 \%$ waste loading and 45 and $50 \%$ total solids.

\subsection{Analytical}

Analyses for this task used guidance of Analytical Study Plan (ASP) SRNL-GPD-2005-00001 (Baich 2005). Sample request forms were used for samples to be analyzed, and analyses followed the guidelines and means of sample control stated in the ASP for the task. A unique ITS and/or Immobilization Technology Section Analytical Laboratory (ITS-AL) lab identification number was assigned to each sample for tracking purposes. Analyses were performed using approved analytical and Quality Assurance (QA) procedures.

The sludge simulant was analyzed as part of the sludge fabrication process; therefore, those results were used to support this testing and no discussion of the methods will be presented here. Samples were taken throughout the run and of the SRAT and SME products to evaluate the process chemistry. In-process supernate and slurry samples were taken in both of the runs to help support an ITS program on understanding the SRAT chemical reactions. The samples were analyzed at the ITS-AL and ACTL. The ITS-AL performed analyses on the in-process and product samples to determine the chemical composition, total and dissolved solids, density, and $\mathrm{pH}$. The chemical composition was determined in duplicate by calcining the samples at $1100^{\circ} \mathrm{C}$ and then dissolving the product using $\mathrm{Na}_{2} \mathrm{O}_{2} / \mathrm{NaOH}$ fusion and a lithium metaborate fusion. The preparations were then analyzed using Inductively Coupled Plasma - Atomic Emission 
Spectroscopy (ICP-AES) to measure the cations present. The in-process samples were centrifuged immediately after pulling the samples from the SRAT vessel in an attempt to stop the reactions occurring with the other solids. The centrifuged supernates were analyzed by ICP-AES. For the SRAT products, the products were filtered using a $0.45 \cdot \mathrm{m}$ filter and the separated supernates were analyzed using ICP-AES to determine the soluble cations present. Testing by Koopman (2005) has shown that solids can form in the SRAT product supernate, so filtering the sample removes any solids that may have formed. Sludge samples for anion analyses were prepped using weighted dilutions and were analyzed using Ion Chromatography (IC). The in-process supernates were also analyzed on the IC to determine the soluble anions. The total and dissolved solids were measured on two aliquots and the insoluble and soluble solids fractions were calculated from the results. Density and $\mathrm{pH}$ measurements of the samples were also performed on the in-process samples. Rheological properties (yield stress and plastic viscosity) were measured and evaluated as a function of the test conditions.

Gases were monitored during the runs using a high-speed Agilent model 3000 micro Gas Chromatograph (GC) to provide insight into the reactions occurring during processing and to determine whether a flammable mixture was formed. As mentioned above, helium was used as a purge gas tracer. Two calibration standards were used to calibrate the GCs before each run to attempt to bound the quantities of the expected gases. The concentrations of these calibration standards were $0.5 \mathrm{~mol} \%$ helium, 0 and $1 \mathrm{~mol} \%$ hydrogen, 0 and $21 \%$ oxygen, 55 and $66.5 \mathrm{~mol} \%$ nitrogen, $2.5 \mathrm{~mol} \%$ nitrous oxide, $0.5 \mathrm{~mol} \%$ carbon monoxide, $20 \mathrm{~mol} \%$ carbon dioxide, and 0 and $10 \mathrm{~mol} \%$ nitric oxide. Calibration checks were performed before and after each run.

The GC is self-contained and is designed specifically for fast and accurate analysis. The GCs have five main components. The first is the carrier gas (argon for this testing) to transport the sample through the MolSieve 5A PLOT (Channel A) and PLOT Q (Channel B) columns. The second is the injector, which introduces a measured amount of sample into the inlet of the analytical columns where it is separated. Injection time is 50 milliseconds for the Channel A gases (helium, hydrogen, nitrogen, oxygen, nitric oxide and carbon monoxide) and 100 milliseconds for the Channel B gases (carbon dioxide and nitrous oxide). The third component is the column, which is capillary tubing coated or packed with a chemical substance known as the stationary phase that preferentially attracts the sample components. As a result, components separate as they pass through the column based on their solubility. Since solubility is affected by temperature, column temperature is controlled during the run. The Channel A column is set at $60^{\circ} \mathrm{C}$, while the Channel B column is set at $70^{\circ} \mathrm{C}$. The fourth component is a micro-machine thermo conductivity detector. The solid state detector monitors the carrier and senses a change in its composition when a component in the sample elutes from the column. The fifth component is the data system, Cerity. Its main purpose is to generate both qualitative and quantitative data. It provides a visual recording of the detector output and an area count of the detector response. The detector response is used to identify the sample composition and measure the amount of each component by comparing the area counts of the sample to the analysis of known calibration standards. A sample was taken every 4 minutes. 
WSRC-TR-2005-00493

Revision 0

This page intentionally left blank. 


\subsection{RESULTS}

Data and observations from the testing will be discussed in this section. This section has been divided into four subsections. Section 3.1 discusses the necessary inputs for the acid calculation. Section 3.2 discusses the general observations about processing and presents the data from the in-process samples. Section 3.3 discusses the generated gas data and the results of the condensate analyses. Finally, section 3.4 discusses the SRAT and SME product characterization.

\subsection{Acid Addition Calculation Inputs}

The sludge composition, target noble metals concentrations, and the target mercury content were discussed in Section 2.1. No samples of the sludge simulant after trimming the noble metals, mercury, and flush water were taken, since the addition amounts were small and flush water was removed during concentration. Therefore, very little difference was expected in the analytical results. Table 3-1 provides the inputs for the acid addition calculation. Initial estimates of nitrite to nitrate conversion and formate destruction were based upon the results of testing with the "Baseline" SB4 composition when Tank 4 was included (Baich et al. 2005). The main difference in the input to the acid calculation was the acid stoichiometry, which also resulted in a slight change in the ratio of formic to nitric acid to maintain the target redox. Although only one SME cycle was performed with the combined SRAT products, both acid calculations required SME inputs so the redox could be accurately targeted. After the SRAT cycles were performed, measured total and calcined solids of the two products were used to more accurately estimate the frit addition and the target dewater to meet the target total solids for the combined SME cycle.

Table 3-1: Pre-Run Measured Inputs and Assumptions for Acid Calculation

\begin{tabular}{|c|c|c|}
\hline Input Parameter & SB4-19 & SB4-20 \\
\hline Nitrite (mg/kg) & 20200 & 20200 \\
\hline Nitrate (mg/kg) & 13700 & 13700 \\
\hline TIC (mg/kg) & 1048 & 1048 \\
\hline Base Equivalents. (M) & 0.562 & 0.562 \\
\hline Mn (wt\% in total solids) & 2.70 & 2.70 \\
\hline Total Solids (wt\%) & 17.8 & 17.8 \\
\hline Density (g/ml) & 1.15 & 1.15 \\
\hline Calcine Factor & 0.688 & 0.688 \\
\hline Hg (wt\% in total solids) & 1.0 & 1.0 \\
\hline Nitrite to Nitrate Conversion in the SRAT & 10 & 10 \\
\hline Formate Destruction in the SRAT/SME & $24 / 0$ & $24 / 0$ \\
\hline Sludge Simulant Mass (g) & 2714.5 & 2731.4 \\
\hline Acid Stoichiometry & $130 \%$ & $170 \%$ \\
\hline Redox Target & 0.2 & 0.2 \\
\hline Ratio of Formic to Nitric & 0.9201 & 0.8842 \\
\hline Moles of Acid/Liter of Slurry & 1.625 & 2.125 \\
\hline Assumed SME Density (g/ml) & 1.45 & 1.45 \\
\hline Waste Loading Target & $43 \%$ & $43 \%$ \\
\hline Frit Slurry Density (g/ml) & 1.50 & 1.50 \\
\hline Frit Slurry Formic Acid Ratio (g/100 g frit slurry) & 1.50 & 1.50 \\
\hline Total Solids Target for SME Product & $50 \%$ & $50 \%$ \\
\hline
\end{tabular}




\subsection{Processing Observations and In-Process Sample Results}

The SRAT runs were performed simultaneously in two different hoods at the ACTL in 4-liter vessels. The sludge was added first and then trim chemicals were added. Flush water was used to clean the sludge and trim chemical containers. An additional $100 \mathrm{~g}$ of flush water was added to each vessel to help with mixing due to the very thick nature of the sludge simulant. When the SRAT cycles commenced, a mixing speed of $450 \mathrm{rpm}$ was necessary to maintain thorough mixing. Once heating commenced, $200 \mathrm{ppm}^{\text {antifoam }}{ }^{3}$ was added at $40^{\circ} \mathrm{C}$ to both vessels. Samples from both vessels were taken at $93^{\circ} \mathrm{C}$ and these were termed the "Pre-Nitric" samples. The target nitric acid amounts were added and then the "End of Nitric" samples were taken. Formic acid addition was initiated. The slurry began to thin noticeably and the mixing speed was reduced slightly. After approximately one third of the formic acid was added, volume expansion of the slurry and significant bubble production was evident in both vessels. The height of the sludge was controlled through adjustment of the mixing speed and no additional antifoam was necessary. After the completion of formic acid addition, the "End of Formic" samples were taken and mixing speed was reduced to $\sim 300 \mathrm{rpm}$. The vessels were ramped to boiling for concentration and reflux and $500 \mathrm{ppm}$ of antifoam was added. Once boiling was initiated, dewatering of the SRAT contents was completed and included $50 \mathrm{~g}$ of the $100 \mathrm{~g}$ of flush water added at the beginning of the SRAT to thin the simulant. For the SB4-19 run, the mixing speed was decreased to $230 \mathrm{rpm}$ but had to be increased back to $300 \mathrm{rpm}$ to maintain mixing. In the SB4-20 run, mixing was maintained at $300 \mathrm{rpm}$ during dewater. After concentration was completed, reflux mode was initiated and was performed for 12 hours. Samples were taken 6 hours into reflux from both kettles. For the SB4-19 run, the mixing speed was maintained at $300 \mathrm{rpm}$ throughout reflux, while it was reduced to $280 \mathrm{rpm}$ for the SB4-20 run. Heat was removed from both kettles at the end of reflux and mixing was stopped once the temperatures dropped below $50^{\circ} \mathrm{C}$. Samples were then taken for characterization, and the mass of the SRAT products was measured.

To support the ITS program to understand the acid addition equation and to model the SRAT chemistry, sludge slurry and supernate samples were taken throughout the runs. For the SB4-19 run, four slurry and four supernate samples were taken for characterization. In the SB4-20 run, only the four supernate samples were taken. As discussed above, sampling occurred just before nitric acid addition was initiated, immediately after nitric acid addition was completed, after formic acid addition was completed, and six hours into reflux. The goal of the sampling was to understand process chemistry by monitoring the changes in anion concentrations, solids content, and soluble elemental species. The supernate anion data is presented in Table 3-2. The SRAT product anions are not included in the table since they were measured on the slurry. The SRAT product anions will be discussed in Section 3.4.

\footnotetext{
${ }^{3}$ In the ACTL demonstrations, IIT 747 antifoam is diluted 1 to 10 with water. The concentration of material added is based on the antifoam in the dilution to the total slurry mass (i.e., $200 \mathrm{mg}$ of dilute antifoam or $20 \mathrm{mg}$ of antifoam per every $\mathrm{kg}$ of sludge).
} 
Table 3-2: Supernate Anion Data for In-Process Samples (mg/kg)

\begin{tabular}{||c|c|c|c|c||}
\hline Run & Sample Point & Nitrite & Nitrate & Formate \\
\hline \multirow{4}{*}{ SB4-19 } & Pre Nitric & 23600 & 17200 & $<100$ \\
\cline { 2 - 5 } & End of Nitric & 22650 & 23850 & $<100$ \\
\cline { 2 - 5 } & End of Formic & 4300 & 29100 & 50000 \\
\cline { 2 - 5 } & 6 hrs into reflux & $<100$ & 32400 & 51450 \\
\hline \multirow{4}{*}{ SB4-20 } & Pre Nitric & 22950 & 16250 & 126 \\
\cline { 2 - 5 } & End of Nitric & 21950 & 28950 & $<100$ \\
\cline { 2 - 5 } & End of Formic & 283 & 37300 & 60650 \\
\cline { 2 - 5 } & 6 hrs into reflux & $<100$ & 44000 & 67000 \\
\hline
\end{tabular}

Note: Results represent an average of two measurements.

The data show a decrease in nitrite concentration, increase in nitrate concentration, and increase in formate concentration over time. Nitrite concentration was below the detection limit 6 hours into reflux for the SB419 run at 130\% stoichiometry, while nitrite was below the DWPF limit at the end of formic acid addition for the SB4-20 run at 170\% stoichiometry. These data indicate that nitrite destruction was easily accomplished at the tested acid stoichiometries and that the lower acid stoichiometry could have been slightly reduced and still met the nitrite destruction limit. Hydrogen generation would be anticipated to occur after nitrite destruction based on historical testing. Although some analytical uncertainty may be present in the data, the data trends indicate that nitrite conversion to nitrate was occurring during acid addition and continued into reflux. Conversion was likely enhanced with the nitrogen species present in the MWWT. Formate destruction appeared to occur mostly after 6 hours into reflux.

The elemental supernate data from the in-process samples are given in Table 3-3. Only those elements that indicated differences from sample to sample or had appreciable solubility are given. The data is also graphically represented in Figure 3-1 and Figure 3-2. Supernate data from the SRAT products are also included in the figures for comparison.

Generally speaking, solubility of most of the elements increased as acid was added and the materials were processed. Increased solubility was also generally seen with increased acid addition level. This behavior would be anticipated for most of the elements based on the chemical reactions that are occurring with the added nitrate and formate. $\mathrm{Al}, \mathrm{Cr}$, and $\mathrm{Pd}$ became less soluble as the formic acid was added and SRAT processing continued. For the other noble metals, $\mathrm{Rh}$ and $\mathrm{Ru}$ were insoluble through nitric acid addition, became soluble during formic acid addition, and then their solubility decreased during reflux. Only very small changes in the leachate concentrations were seen between the two acid levels. These species were added as soluble forms and reacted to become less insoluble during processing. 
Table 3-3: Elemental Supernate Data from In-Process Samples (mg/L)

\begin{tabular}{|c|c|c|c|c|c|c|c|c|c|c|}
\hline Test & Sample & Al & $\mathbf{B a}$ & $\mathbf{C a}$ & $\mathrm{Ce}$ & $\mathrm{Cr}$ & $\mathbf{C u}$ & $\mathbf{F e}$ & Mg & Mn \\
\hline \multirow{4}{*}{ SB4-19 } & Pre-Nitric & 3020 & $<0.100$ & 0.53 & 0.637 & 26.2 & 0.340 & $<0.100$ & $<0.100$ & $<0.100$ \\
\hline & End Nitric & 1730 & $<0.100$ & 0.465 & 0.64 & 25.9 & 0.334 & $<0.100$ & $<0.100$ & $<0.100$ \\
\hline & End Formic & 110 & 0.985 & 2090 & 5.63 & 0.773 & 51.8 & 3.50 & 626 & 2905 \\
\hline & 6hr Reflux & 2.52 & 1.66 & 2205 & 0.838 & $<0.100$ & 0.655 & 0.324 & 692 & 2410 \\
\hline \multirow{4}{*}{ SB4-20 } & Pre-Nitric & 2780 & $<0.100$ & 0.52 & 0.636 & 25.8 & 0.332 & $<0.100$ & $<0.100$ & $<0.100$ \\
\hline & End Nitric & 1245 & $<0.100$ & 1.53 & 0.697 & 25.7 & 0.334 & $<0.100$ & $<0.100$ & $<0.100$ \\
\hline & End Formic & 636 & 1.38 & 2115 & 13.0 & 5.12 & 68.1 & 96.4 & 681 & 3435 \\
\hline & 6hr Reflux & 40.5 & 1.83 & 2605 & 31.2 & 0.157 & 3.30 & 938 & 821 & 4190 \\
\hline Test & Sample & $\mathrm{Na}$ & $\overline{\mathrm{Ni}}$ & $\mathbf{P b}$ & Pd & Rh & Ru & $\overline{\mathrm{S}}$ & $\overline{\mathrm{Si}}$ & $\overline{Z Z n}$ \\
\hline \multirow{4}{*}{ SB4-19 } & Pre-Nitric & 27600 & $<0.100$ & $<0.200$ & 12.7 & $<1.000$ & $<1.000$ & 621 & 110 & $<0.100$ \\
\hline & End Nitric & 28850 & $<0.100$ & $<0.200$ & 8.74 & $<1.000$ & $<1.000$ & 633 & 49.9 & $<0.100$ \\
\hline & End Formic & 28200 & 464 & $<0.200$ & $<1.000$ & 53.4 & 69.8 & 413 & 29.0 & 46.1 \\
\hline & 6hr Reflux & 33100 & 5.86 & $<0.200$ & $<1.000$ & 1.02 & $<0.100$ & 400 & 53.4 & $<0.100$ \\
\hline \multirow{4}{*}{ SB4-20 } & Pre-Nitric & 28700 & $<0.100$ & $<0.200$ & 12.1 & $<1.000$ & $<1.000$ & 617 & 95.1 & $<0.100$ \\
\hline & End Nitric & 27750 & $<0.100$ & $<0.200$ & 6.89 & $<1.000$ & $<1.000$ & 618 & 48.5 & $<0.100$ \\
\hline & End Formic & 27900 & 619 & 1.80 & $<1.000$ & 8.41 & 54.1 & 425 & 29.0 & 73.0 \\
\hline & 6hr Reflux & 33700 & 662 & 3.78 & $<1.000$ & 1.48 & 10.2 & 532 & 66.9 & 97.2 \\
\hline
\end{tabular}

Figure 3-1: Supernate Data Comparison - Higher Concentrations

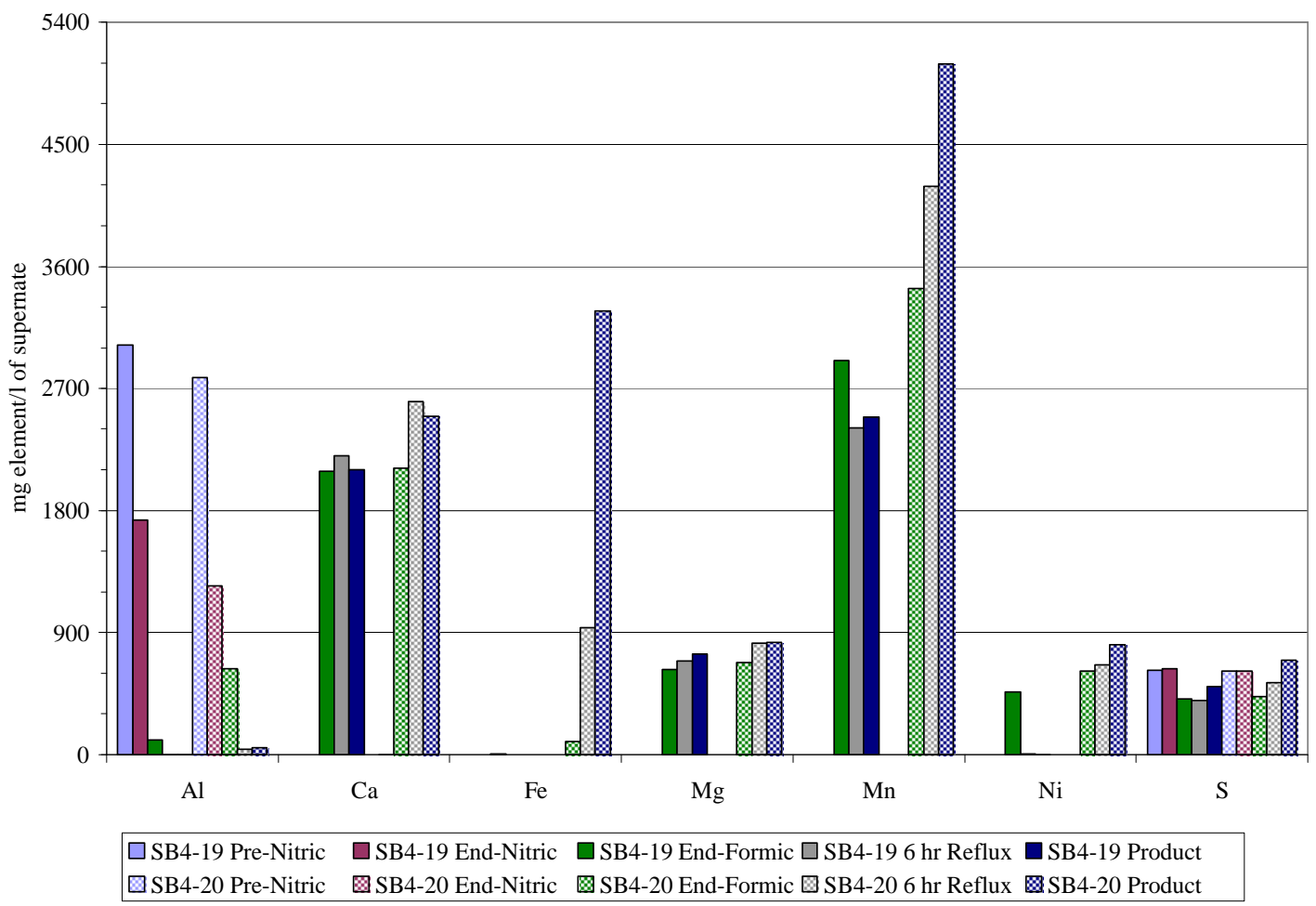


Figure 3-2: Supernate Data Comparison - Lower Concentrations

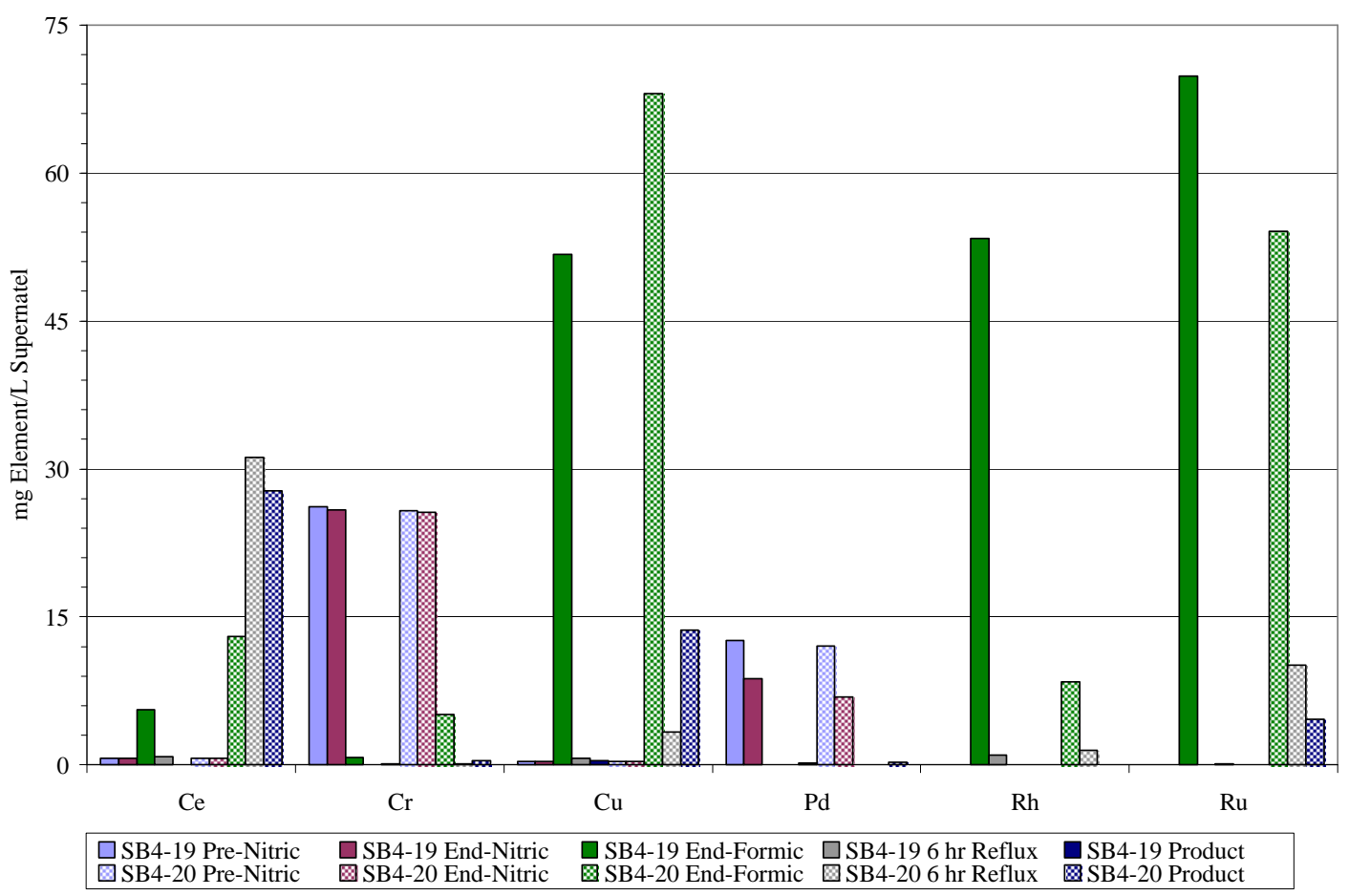

Approximately one week after the SRAT cycles were performed, $\sim 1500 \mathrm{~g}$ of each SRAT product was combined and the SME cycle was performed. The starting SME feed was thinner than the starting SRAT feed, and the mixer was operated at $250 \mathrm{rpm}$ through the first frit addition and processing. After the second frit addition, the mixing speed had to be increased to $300 \mathrm{rpm}$. With the last $\sim 100 \mathrm{~g}$ to dewater, the mixing speed had to be increased to $350 \mathrm{rpm}$ due to the increasing thickness. The $\mathrm{pH}$ increased steadily throughout SME processing starting slightly below 5 and ending around 5.4.

\subsection{Generated Off Gas Data and Condensate Analyses}

As mentioned in Section 2.3, GCs were used to measure hydrogen, oxygen, nitrogen, carbon dioxide, carbon monoxide, nitric oxide, and nitrous oxide throughout the runs. No carbon monoxide was detected in any of the runs. Carbon monoxide has not been detected in any of the SB4 runs and was only seen in a couple of runs during SB3 testing where oxygen was completely depleted (Herman et al. 2003). Complete GC data from the two SRAT runs are given as Figure 3-3 and Figure 3-4. No appreciable amounts of gases were generated during nitric acid addition, and carbon dioxide began evolving with the start of formic acid addition during both SRAT runs. Approximately 2 hours after the start of formic addition, nitrous oxide and nitric oxide began evolving. Oxygen concentration decreased during this same period; however, it did not go to zero as seen in SB3 testing (Herman et al. 2003) but was lower than concentrations seen in earlier SB4 testing (Baich et al. 2005). Hydrogen began to evolve after reflux in the SB4-19 run and after going to boiling in the SB4-20 run. No significant amounts of gases were detected approximately three hours into reflux for the SB4-19 run, while small amounts of carbon dioxide and hydrogen were detected throughout reflux in the SB4-20 run. Figure 3-5 and Figure 3-6 show a subset of the GC data where most of the peaks and gases were being generated. These plots help distinguish the peaks and identify reactions and changes during processing. 
WSRC-TR-2005-00493

Revision 0

Figure 3-3: SB4-19 GC Data

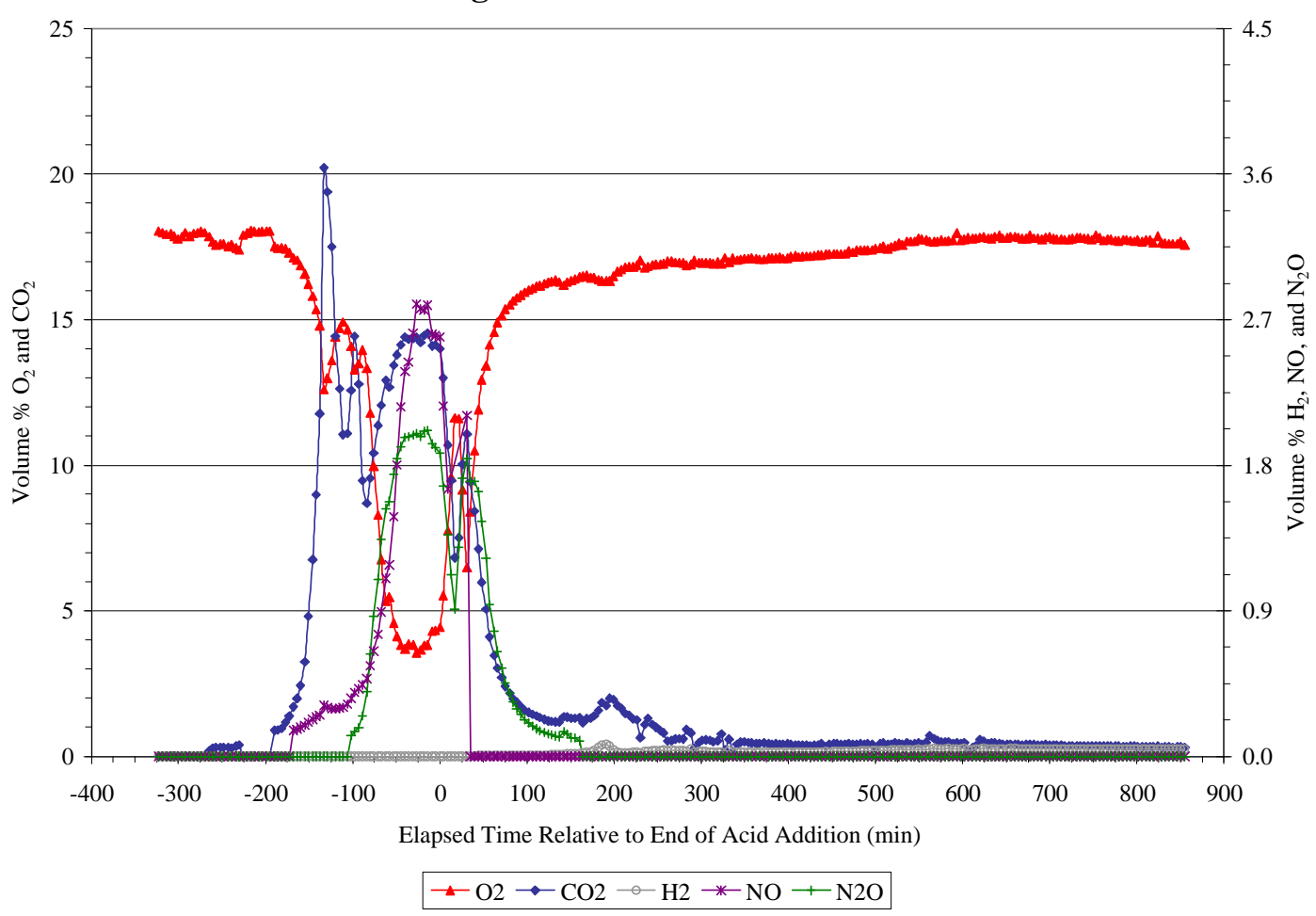

Figure 3-4: SB4-20 GC Data

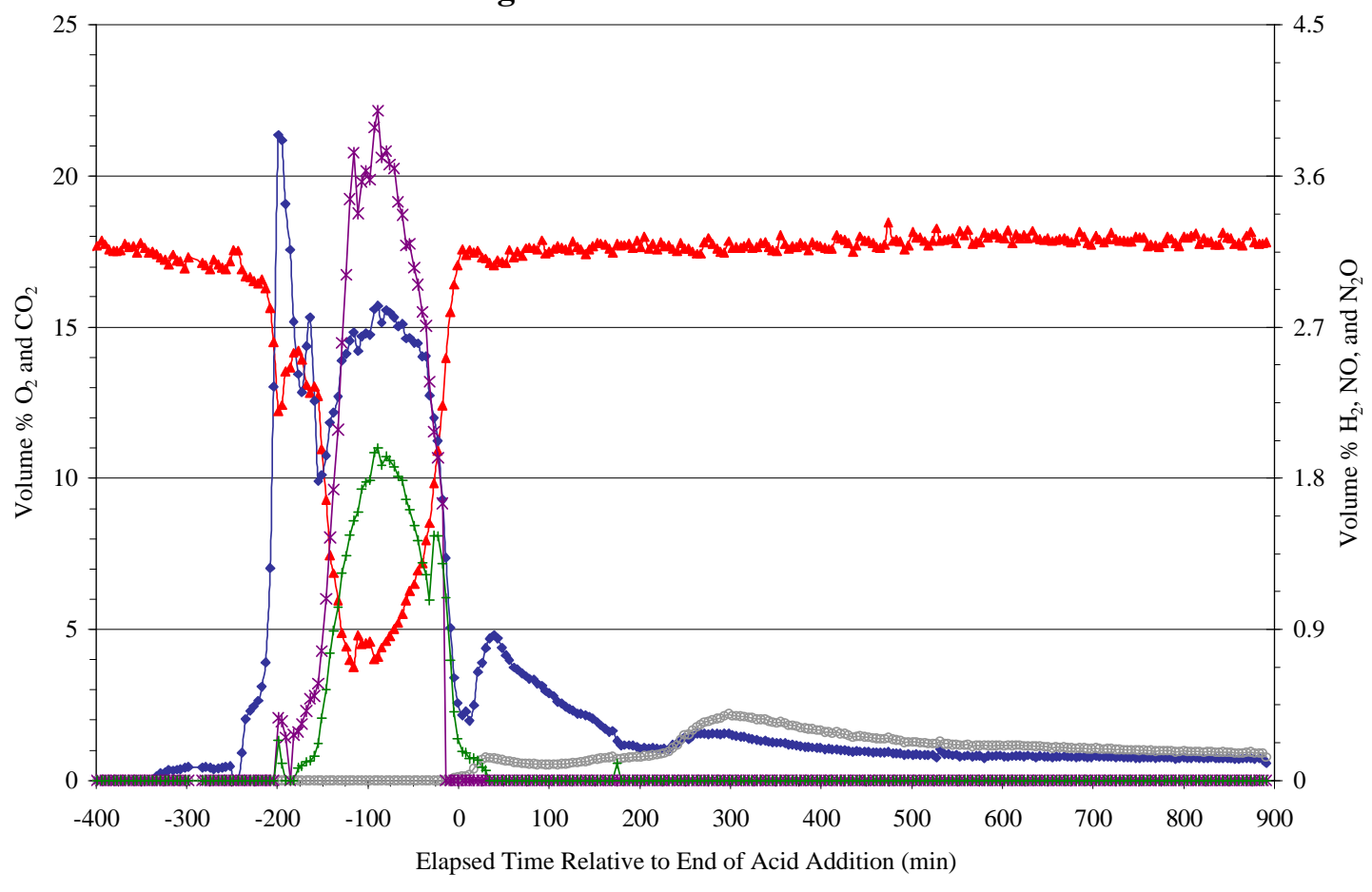

$\rightarrow-\mathrm{O} 2 \rightarrow-\mathrm{CO} 2 \rightarrow-\mathrm{H} 2 \rightarrow \mathrm{NO}+\mathrm{N} 2 \mathrm{O}$ 
WSRC-TR-2005-00493

Revision 0

Figure 3-5: Subset of SB4-19 GC Data

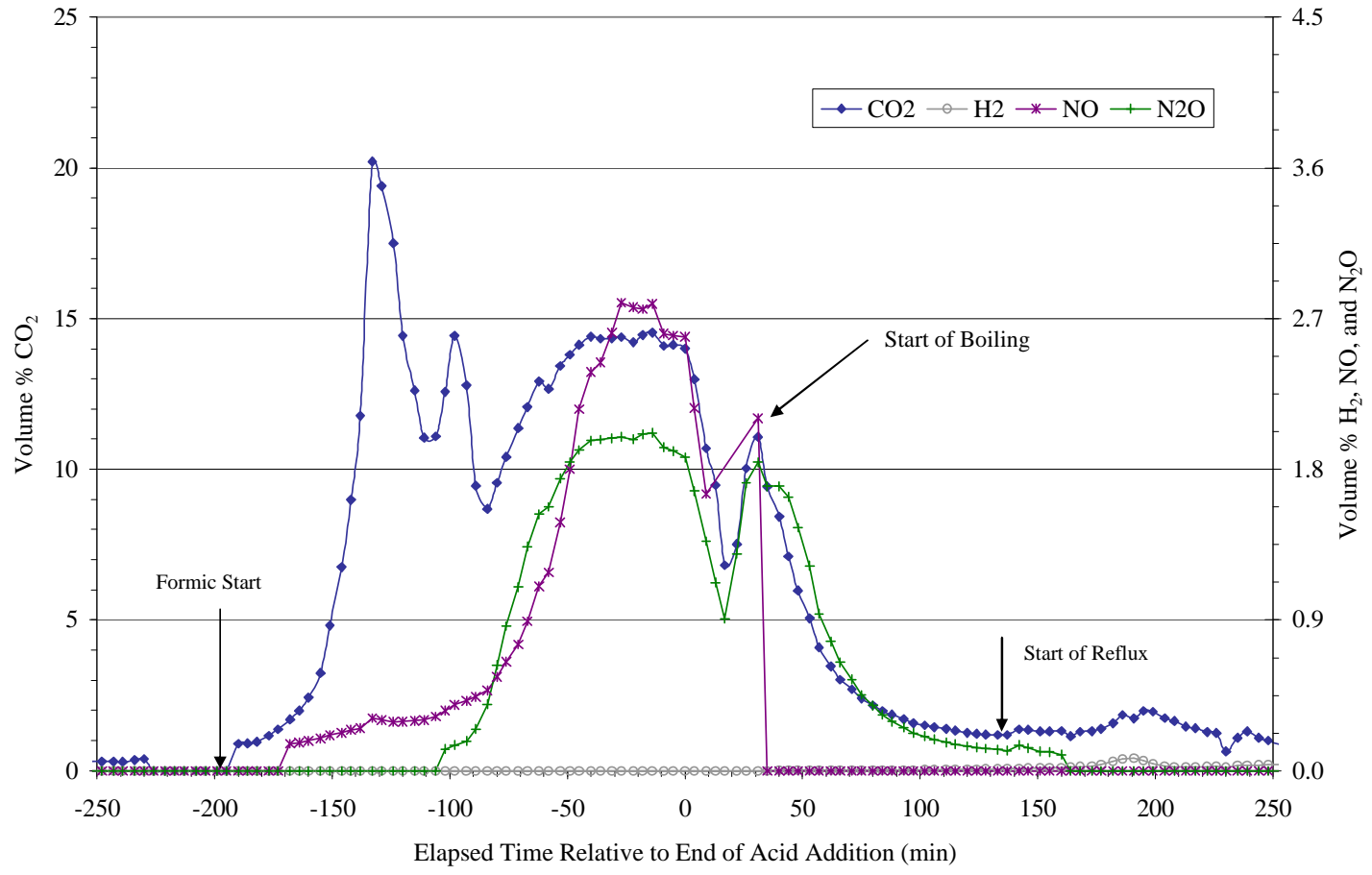

Figure 3-6: Subset of SB4-20 GC Data

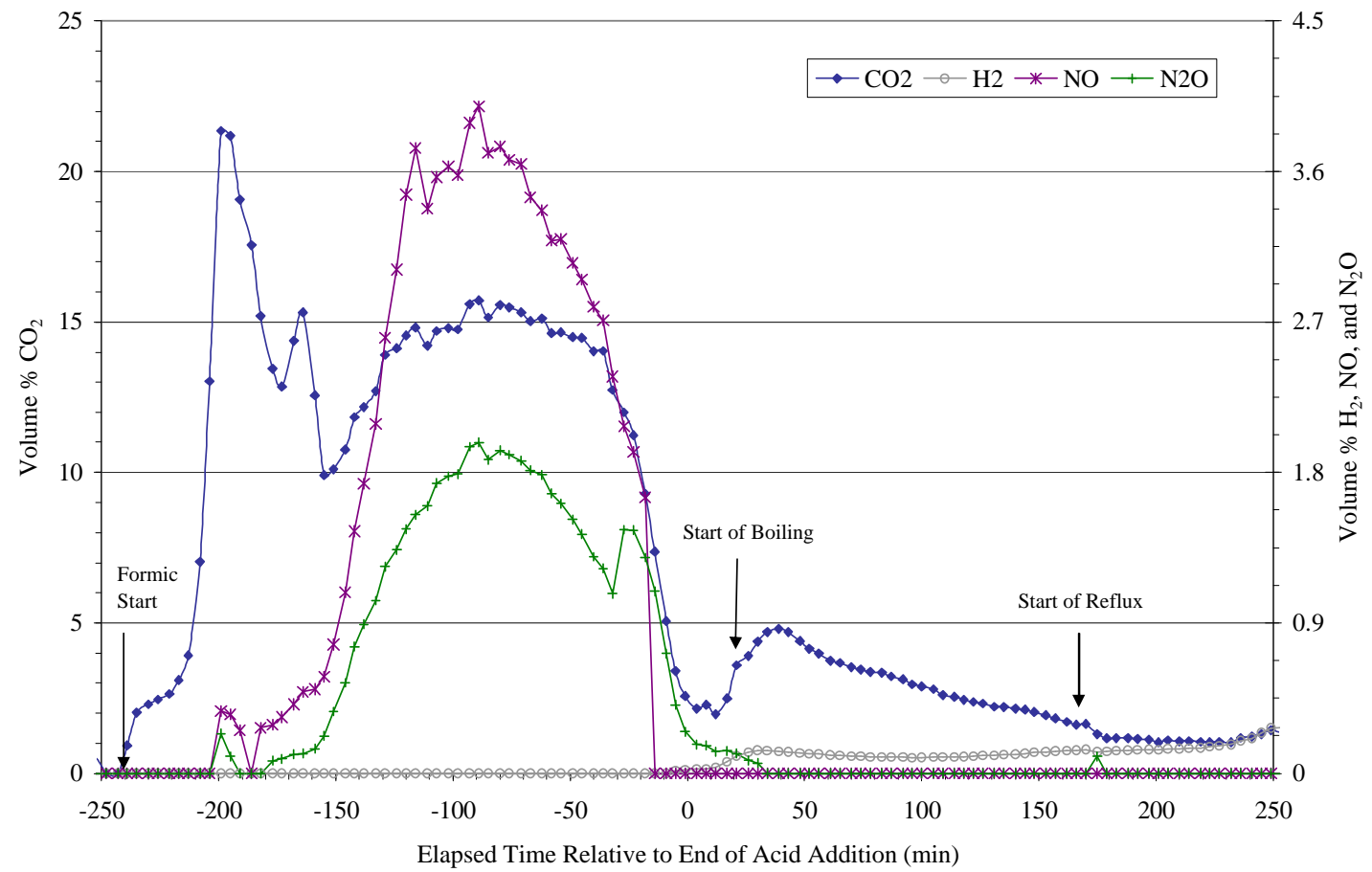


The initial carbon dioxide peaks are typically associated with carbonate and nitrite destruction. The two runs had similar gas generation behavior when the longer acid addition time of the SB4-20 run is considered. The nitrous oxide, nitric oxide, and secondary carbon dioxide peaks started after roughly the same amount of acid was added. The peak widths for the SB4-20 run were greater due to the longer acid addition time, but had decreased significantly before the end of acid addition. Gas generation continued into boiling for the SB4-19 run supporting the data in Table 3-2 that nitrite had not been completely destroyed. The shape and timing of the peaks is slightly different than what was seen in earlier SB4 testing (Baich et al. 2005), but was similar to the behavior seen in SB3 flowsheet testing (Herman et al. 2003). Minor peaks are also seen at the onset of boiling and reflux. Based on the hydrogen data and the in-process data from Table 3-2, nitrite was probably destroyed at around 200 minutes for the SB4-19 run and after going to boiling for the SB4-20 run.

Table 3-4 presents the peak gas concentrations. The data for hydrogen has also been converted to DWPF scale generation rate in $\mathrm{lb} / \mathrm{hr}$ based on scaling the SRAT volume to a nominal 6,000 gallon DWPF SRAT volume. The carbon dioxide peak values were similar to those seen in the higher acid runs with the previous SB4 simulant (Baich et al. 2005). Nitric oxide peaks were slightly higher and nitrous oxide peaks slightly lower than the runs with $\mathrm{Hg}$ in earlier SB4 testing (Baich et al. 2005). Compared to SB3 simulant flowsheet runs and the Shielded Cells run with the combination of SB2 and SB3 sludge (Herman et al. 2003 and Bannochie et al. 2004), the nitrous oxide peak is occurring at a slightly later time in the SRAT cycle. In the referenced runs, nitrous oxide usually peaked by the end of acid addition. The peak hydrogen value for SB419 was $\sim 1 / 10$ of the DWPF SRAT limit, while the value for the SB4-20 was $~ 1 / 2$ the DWPF SRAT limit.

Table 3-4: Peak Gas Concentrations and Hydrogen Generation Rates

\begin{tabular}{|c|c|c|c|c|c|}
\hline RUN & $\begin{array}{c}\text { Peak } \mathrm{CO}_{2} \\
(\mathrm{Vol} \%)\end{array}$ & $\begin{array}{c}\text { Peak NO } \\
(\text { Vol\%) }\end{array}$ & $\begin{array}{c}\text { Peak } \mathrm{N}_{2} \mathrm{O} \\
(\text { Vol\%) }\end{array}$ & $\begin{array}{c}\text { Peak } \mathbf{H}_{2} \\
(\text { Vol\%) }\end{array}$ & $\begin{array}{c}\text { Peak H } \mathrm{H}_{2}- \\
\text { DWPF scale } \\
(\mathrm{Lb} / \mathrm{hr})\end{array}$ \\
\hline SB4-19 & 20.214 & 2.796 & 2.017 & 0.075 & 0.058 \\
\hline SB4-20 & 21.356 & 3.990 & 1.980 & 0.395 & 0.301 \\
\hline
\end{tabular}

Note: The GC records mole \% data, but because the ideal gas law is assumed, then mole \% equals volume \%. DWPF scale is based on an assumed DWPF SRAT volume of 6,000 gallons.

The condensate samples from the run were analyzed for anions, $\mathrm{pH}$, density, and major elements. The data is given in Table 3-5. The FAVC condensate contained high levels of nitrate in both runs and were very acidic (i.e., $\mathrm{pH}<1$ ). Overall, the SB4-20 condensates contained more formate than the SB4-19 condensates. The condensate data may also support the destruction of nitrite by the end of dewater for the SB4-20 run since no nitrite was detected in the dewater condensate. The elemental species could not be determined for the SB419 FAVC sample due to insufficient sample mass. The condensate data was consistent with trends seen in previous SB4 testing (Baich et al. 2005) with slightly lower nitrate concentrations in the dewater due to the refluxing that was performed in acid addition in this set of testing. The FAVC sample was also submitted for Gas Chromatography - Semi Volatile Organic Analysis. A small amount of chloromethyl mercury was detected in the sample. This phase had previously been found in testing with the Modular Caustic Side Solvent Extraction Unit (MCU) stream. It was not clear whether the phase was present because of the MCU organics or the antifoam used in the process. This testing verified that the phase could form in the presence of the antifoam organics. 
WSRC-TR-2005-00493

Revision 0

Table 3-5: Condensate Sample Results (mg/L)

\begin{tabular}{|c|c|c|c|c|c|c|c|c|}
\hline Test & Sample & $\mathrm{NO}_{2}$ & $\mathrm{NO}_{3}$ & $\mathrm{HCO}_{2}$ & Al & Ca & $\mathbf{F e}$ & pH \\
\hline \multirow{3}{*}{ SB4-19 } & Dewater & 470 & 7985 & 919 & 0.121 & 0.084 & $<0.010$ & 1.01 \\
\hline & FAVC & 152 & 259500 & 442 & N/A & N/A & N/A & $<1.00$ \\
\hline & MWWT & $<100$ & 242 & $<100$ & 0.094 & 0.327 & $<0.010$ & 8.02 \\
\hline \multirow{3}{*}{ SB4-20 } & Dewater & $<100$ & 1560 & 5535 & 0.100 & 0.095 & $<0.010$ & 1.60 \\
\hline & FAVC & 146 & 260000 & 641 & 0.234 & 0.288 & 0.511 & $<1.00$ \\
\hline & MWWT & $<100$ & 626 & 1025 & 0.094 & 0.046 & $<0.010$ & 2.00 \\
\hline Test & Sample & K & Mg & Mn & $\mathrm{Na}$ & Si & & Density $(\mathrm{g} / \mathrm{ml})$ \\
\hline \multirow{3}{*}{ SB4-19 } & Dewater & 0.224 & $<0.010$ & $<0.010$ & $<0.100$ & 60.3 & & 1.01 \\
\hline & FAVC & N/A & N/A & N/A & N/A & N/A & & 1.15 \\
\hline & MWWT & 0.210 & 0.119 & 0.076 & $<0.100$ & 46.0 & & 1.00 \\
\hline \multirow{3}{*}{ SB4-20 } & Dewater & 0.161 & $<0.010$ & $<0.010$ & $<0.100$ & 185 & & 1.01 \\
\hline & FAVC & 0.191 & $<0.010$ & 0.394 & 2.07 & 109 & & 1.15 \\
\hline & MWWT & 0.172 & $<0.010$ & $<0.010$ & $<0.100$ & 128 & & 1.00 \\
\hline
\end{tabular}

N/A - Not enough sample for analysis.

Figure 3-7 contains the GC data for the SME run. No nitric oxide was detected in the SME cycle. Gases were generated with each return to boiling after frit addition. Nitrous oxide, hydrogen, and carbon dioxide all peaked at the start of boiling. After the first frit addition, the gases dissipated when boiling was stopped to add the next addition of frit. After the second frit addition, the gases remained at elevated levels during concentration to meet the target total solids. For a brief time in the SME cycle, nitrous oxide concentration could not be detected. No problems with the GC were evident, so the concentration may have been below the detection limit of the GC. The gas generation rates appeared to increase slightly near the end of the cycle, which also corresponded to an increase in the mixing speed at around 400 minutes. The generated gas behavior is similar to the pattern seen in previous SME testing. The peak generation rates for the SME cycle were $7.48 \mathrm{vol} \%$ carbon dioxide, $0.535 \mathrm{vol} \%$ nitrous oxide, and $0.036 \mathrm{vol} \%$ hydrogen or $0.088 \mathrm{lbs} / \mathrm{hr}$ hydrogen on a DWPF scale. The SME hydrogen was $\sim 40 \%$ of the limit. 
Figure 3-7: SME GC Data

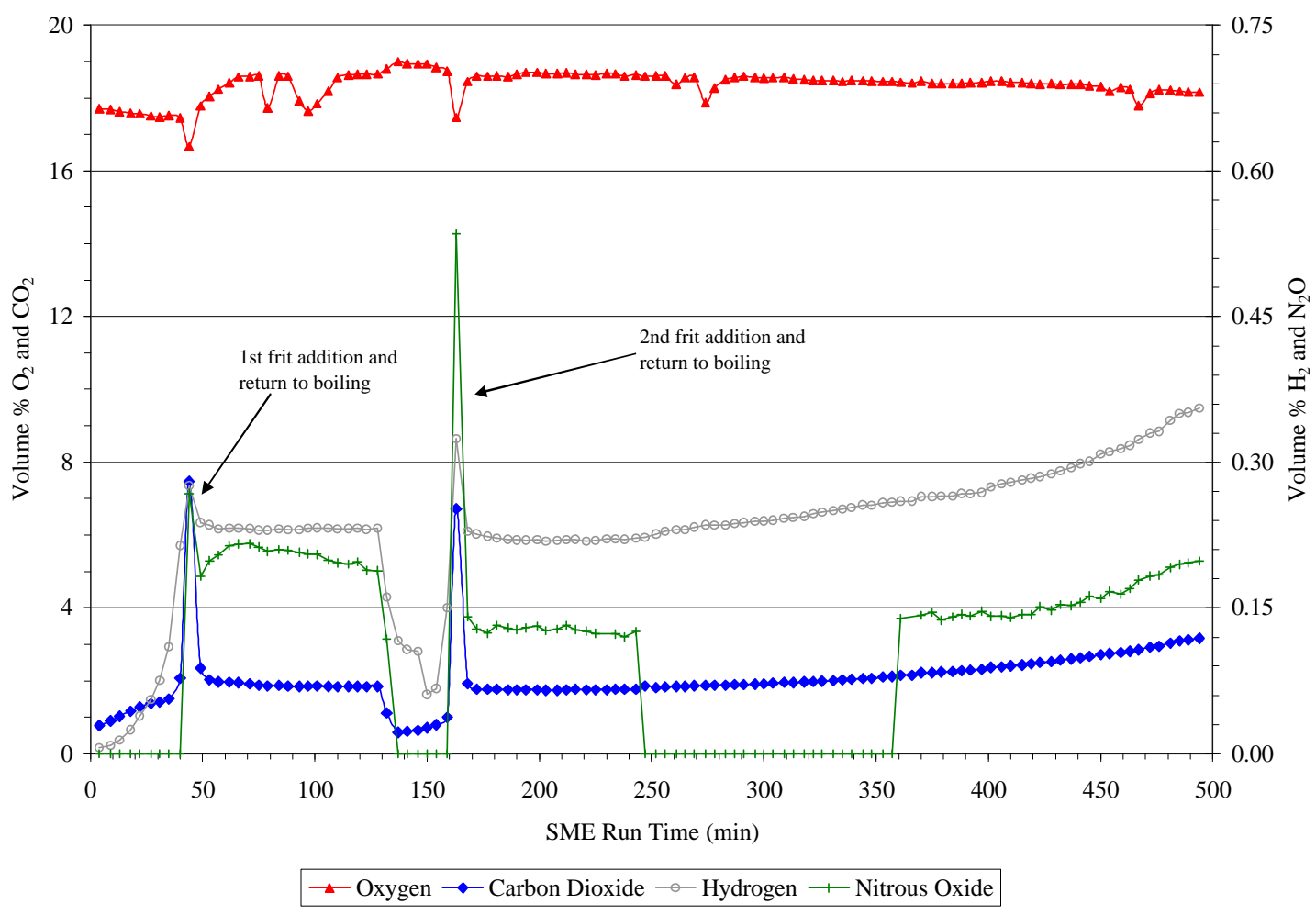

\subsection{SRAT and SME Product Characterization}

For SB4-19, mass balance closure from the SRAT receipt to the SRAT product was within $\sim 2 \%$ with the non-condensable species $\left(\mathrm{CO}_{2}, \mathrm{NO}, \mathrm{N}_{2} \mathrm{O}\right.$, and $\left.\mathrm{H}_{2}\right)$ and FAVC condensate accounting for the mass difference (see Table A - 3 of Attachment A). The SB4-20 run had a poorer closure with a mass balance loss from the SRAT receipt to the SRAT product of $\sim 6 \%$ (see Table A - 4 of Attachment A). The non-condensable species and the FAVC condensate accounted for a little more than half of the loss. The remaining mass loss can be attributed to analytical error, water vapor loss, and/or species that were not detected by the GC. The range of mass loss is consistent with other runs at this scale. The SME mass balance is also given in Attachment A (Table A - 5) and also closed well.

The SRAT products and the SME product were characterized for the anion concentration, cation concentration, solids content, density, and $\mathrm{pH}$. The product anion concentration for each run is given in Table 3-6. All runs successfully destroyed nitrite to below the DWPF limit (<1000 mg/kg).

Table 3-6: SRAT and SME Product Anion Concentrations (mg/kg)

\begin{tabular}{||c|c|c|c||}
\hline Anion & Nitrite & Nitrate & Formate \\
\hline SB4-19 & $<100$ & 26,850 & 46,100 \\
\hline SB4-20 & $<100$ & 35,100 & 56,200 \\
\hline SME & $<100$ & 37,100 & 62,800 \\
\hline
\end{tabular}

Note: Analyses performed on weighted dilution of samples.

Results represent an average of two measurements 
The destruction and conversion numbers were estimated based on the material balance and the product anion concentration numbers. The percent conversion of nitrite to nitrate and percent destruction of formate during the SRAT process is given in Table 3-7. The conversions/destructions for the SRAT runs are calculated based on the amount of nitrite, nitrate, and formate in the simulant and added during processing versus the amount that is present in the SRAT product. The nitrite to nitrate conversion was two times the estimated number at the start of the SRAT. The estimated numbers were based on the previous SB4 testing (Baich et al. 2005). Formate destruction was close to the estimates and slightly higher with the higher acid stoichiometry. The SME cycle showed very minor destruction of nitrate and formate, which was greater than assumed since no destruction in the SME cycle was assumed.

Table 3-7: Conversion of Nitrite to Nitrate, Destruction of Nitrate and Formate - Receipt Relative to Product

\begin{tabular}{||c|c|c|c|c|c||}
\hline \multirow{2}{*}{ Run ID } & \multicolumn{2}{|c|}{$\begin{array}{c}\text { Nitrite to Nitrate \% } \\
\text { Conversion }\end{array}$} & $\begin{array}{c}\text { \% Nitrate } \\
\text { Destruction }\end{array}$ & \multicolumn{2}{|c|}{ \% Formate Destruction } \\
\cline { 2 - 6 } & Projected & Measured & Measured & Projected & Measured \\
\hline SB4-19 & 10 & 22.3 & N/A & 24 & 23.2 \\
\hline SB4-20 & 10 & 23.7 & N/A & 24 & 28.6 \\
\hline SME & N/A & N/A & 7.49 & 0 & 10.2 \\
\hline \hline
\end{tabular}

As mentioned in Section 2.3, the products were calcined at $1100^{\circ} \mathrm{C}$ in order to prepare them for cation analyses. The elements detected in the calcined solids are given in Table 3-8.

When the SRAT product compositions are compared with the simulant compositions given in Table 2-1, the SRAT products are a good approximation of the simulant sludge compositions. Therefore, both of the SRATs were performed with representative feed. Based on the Li number and the DWPF waste loading estimate method, the waste loading of the SME product was $40.5 \%$. Therefore, the waste loading was slightly lower than the targeted $43 \mathrm{wt} \%$. Since the waste loading was not known before frit and water additions were made to the SME product for rheology testing, the other SME products (i.e., the three other waste loading and total solids adjusted samples) would also have slightly lower than the targeted waste loadings. 
Table 3-8: Product Results (Calcined Solids Wt\% Basis)

\begin{tabular}{||c|c|c|c||}
\hline & SB4-19 & SB4-20 & SME \\
\hline $\mathbf{A l}$ & 17.7 & 17.5 & 7.84 \\
\hline $\mathbf{B}$ & $<0.100$ & $<0.100$ & 1.34 \\
\hline $\mathbf{B a}$ & 0.126 & 0.126 & 0.061 \\
\hline $\mathbf{C a}$ & 1.59 & 1.63 & 0.60 \\
\hline $\mathbf{C r}$ & 0.154 & 0.153 & 0.015 \\
\hline $\mathbf{C u}$ & 0.073 & 0.040 & 0.031 \\
\hline $\mathbf{F e}$ & 16.7 & 17.0 & 7.05 \\
\hline $\mathbf{K}$ & 0.123 & 0.124 & 0.077 \\
\hline $\mathbf{L i}$ & $<0.100$ & $<0.100$ & 2.22 \\
\hline $\mathbf{M g}$ & 0.606 & 0.625 & 0.32 \\
\hline $\mathbf{M n}$ & 4.03 & 4.28 & 1.73 \\
\hline $\mathbf{N a}$ & 18.3 & 18.6 & 11.6 \\
\hline $\mathbf{N i}$ & 1.09 & 1.10 & 0.451 \\
\hline $\mathbf{P b}$ & $<0.020$ & $<0.020$ & 0.033 \\
\hline $\mathbf{S}$ & 0.382 & 0.382 & 0.152 \\
\hline $\mathbf{S i}$ & 1.16 & 1.15 & 21.1 \\
\hline $\mathbf{T i}$ & 0.029 & 0.029 & 0.023 \\
\hline $\mathbf{Z n}$ & 0.206 & 0.193 & 0.101 \\
\hline $\mathbf{Z r}$ & $<0.010$ & $<0.010$ & 0.013 \\
\hline \hline
\end{tabular}

Note: Two aliquots are removed from the product sample. Each aliquot is then calcined, dissolved, and analyzed. Results represent an average of the two measurements.

The SRAT products were also filtered to remove the supernate, so the soluble components could be determined. The ICP-AES data are given in Table 3-9 in both concentration and in relative solubility. Relative solubility of the elements was determined by considering the amount of supernate present in the samples and the total amount of the particular element in the SRAT product.

Table 3-9: Solubility of Elements in the SRAT Product Supernate

\begin{tabular}{||c|c|c|c|c|c|c|c|c|c||}
\hline Test & Unit & Al & Ba & Ca & Cr & Cu & Fe & Mg & Mn \\
\hline \multirow{2}{*}{ SB4-19 } & $\mathrm{mg} / \mathrm{L}$ & 0.987 & $<0.100$ & 2100 & 0.151 & 13.7 & 3270 & 744 & 2490 \\
\cline { 2 - 11 } & Rel \% & $0.004 \%$ & $\mathrm{ND}$ & $84.3 \%$ & $0.300 \%$ & $0.415 \%$ & $\mathrm{ND}$ & $78.1 \%$ & $39.3 \%$ \\
\hline \multirow{2}{*}{ SB4-20 } & $\mathrm{mg} / \mathrm{L}$ & 53.7 & $<0.100$ & 2495 & 0.431 & 13.7 & 3270 & 830 & 5095 \\
\cline { 2 - 11 } & Rel \% & $0.190 \%$ & $\mathrm{ND}$ & $94.5 \%$ & $0.831 \%$ & $21.3 \%$ & $11.9 \%$ & $82.1 \%$ & $73.6 \%$ \\
\hline \hline \multirow{2}{*}{ Test } & Unit & $\mathbf{N a}$ & $\mathbf{N i}$ & $\mathbf{P b}$ & $\mathbf{P d}$ & $\mathbf{R h}$ & $\mathbf{R u}$ & $\mathbf{S}$ & $\mathbf{Z n}$ \\
\hline \multirow{2}{*}{ SB4-19 } & $\mathrm{mg} / \mathrm{L}$ & 31200 & 1.82 & 1.82 & 0.187 & $<0.100$ & 0.118 & 502 & $<0.010$ \\
\cline { 2 - 10 } & Rel \% & $109 \%$ & $0.107 \%$ & $\mathrm{ND}$ & $0.604 \%$ & $\mathrm{ND}$ & $0.057 \%$ & $83.6 \%$ & $\mathrm{ND}$ \\
\cline { 2 - 10 } & $\mathrm{mg} / \mathrm{L}$ & 31750 & 808 & $<0.100$ & 0.243 & $<0.100$ & 4.62 & 696 & 133 \\
\cline { 2 - 10 } & Rel \% & $106 \%$ & $45.4 \%$ & $\mathrm{ND}$ & $0.739 \%$ & $\mathrm{ND}$ & $2.09 \%$ & $113 \%$ & $42.4 \%$ \\
\hline
\end{tabular}

Sodium was completely soluble in both SRAT products, which was expected. Calcium and $\mathrm{Mg}$ were very soluble due to the creation of formate species from reactions during the SRAT. Nominally, increased solubility was seen at higher acid stoichiometry. The metals, $\mathrm{Ba}, \mathrm{Cr}$, and $\mathrm{Pd}$, showed minimal to no solubility in the SRAT products. Other metals, such as $\mathrm{Cu}, \mathrm{Ni}$, and $\mathrm{Ru}$, showed increased solubility at the 
higher acid stoichiometry. The Ni solubilities are closer to what has been seen in previous SB3 testing (Herman et al. 2003) and were anticipated based on anticipated reactions from Hsu (1990). The remaining metals were more soluble in this set of SB4 testing than the previous testing (Baich et al. 2005). Manganese was $40 \%$ soluble in the lower acid run and $75 \%$ soluble in the higher acid run. The current DWPF acid addition equations assume about $40 \%$ of the Mn becomes reduced/soluble during processing. Sulfur was very soluble and was much greater than the solubility seen in the earlier SB4 testing. Iron had a limited solubility in the higher acid test, whereas it normally exhibits no solubility.

The total and dissolved solids were measured on the SRAT and SME products, and the insoluble and soluble solids were then calculated. As mentioned above, the calcined solids were also measured. To complete the property analyses, the slurry density and $\mathrm{pH}$ were measured. The results are given in Table 3-10.

Table 3-10: Additional Property Data on SRAT and SME Products

\begin{tabular}{||c|c|c|c|c|c|c||}
\hline RUN ID & $\begin{array}{c}\text { Total } \\
\text { Solids } \\
(\mathbf{w t} \%)\end{array}$ & $\begin{array}{c}\text { Insoluble } \\
\text { Solids } \\
(\mathbf{w t} \%)\end{array}$ & $\begin{array}{c}\text { Soluble } \\
\text { Solids } \\
(\mathbf{w t} \%)\end{array}$ & $\begin{array}{c}\text { Calcined } \\
\text { Solids } \\
(\mathbf{w t} \%)\end{array}$ & $\begin{array}{c}\text { Slurry } \\
\text { Density } \\
(\mathbf{g} / \mathbf{m l})\end{array}$ & $\mathbf{p H}$ \\
\hline SB4-19 & 21.3 & 11.3 & 10.1 & 13.0 & 1.12 & 7.48 \\
\hline SB4-20 & 22.4 & 10.6 & 11.8 & 13.3 & 1.18 & 5.22 \\
\hline SME & 49.8 & 36.7 & 13.1 & 39.0 & 1.41 & 6.10 \\
\hline
\end{tabular}

Note: Measured on two aliquots from the same sample. Data reported is an average. Total and dissolved solids were actually measured and insoluble and soluble solids were calculated

The solids in this set of runs were lower than the previous SB4 and SB3 runs due to the problems with the thickness of the sludge. The soluble solids are comparable to the soluble solids tested in the earlier SB4 runs (Baich et al. 2005). The soluble solids in this set of runs showed a slight increase as the amount of acid increased, which is anticipated and consistent with the supernate data given above. Overall, the values are consistent with previous studies. The product $\mathrm{pH}$ measurements were performed after the testing was complete, and the trend of lower final $\mathrm{pH}$ with higher acid was evident.

The acid calculation was recalculated with the actual numbers from testing. The actual numbers include: the exact mass of sludge, flush water, noble metals, and mercury; the mass of nitric and formic acid added; the mass of antifoam additions; the mass of dewater and samples removed; and the calculated destructions and conversions based on the SRAT product analyses. After these corrections to the acid addition calculation, the SRAT total solids were predicted to be $20.6 \mathrm{wt} \%$ for the SB4-19 run and 22.3 wt\% for the SB4-20 run. The numbers reported in Table 3-10 are very close to these revised targets. This provides an indication that the ITS acid addition calculation sheet is predicting the reactions that affect the total solids in the SRAT fairly accurately (e.g., solids lost in base equivalent neutralization and water made from nitrite destruction). The revised inputs also indicate slight changes in the acid stoichiometry and redox. For SB4-19, acid stoichiometry was $129.4 \%$ with a $\mathrm{Fe}^{+2} / \bullet \mathrm{Fe}$ redox of 0.140 , while SB4-20 was at $169.7 \%$ acid and 0.099 $\mathrm{Fe}^{+2} / \bullet \mathrm{Fe}$ redox. The acid numbers were close to the projections, while the redox projections were low due to nitrite to nitrate conversion assumptions being too low.

Mercury at $1 \mathrm{wt} \%$ total solids basis was added to the SRAT feed before processing was initiated. As stated earlier, this level was anticipated to be conservative from a hydrogen generation perspective based on preliminary SB4 analyses. Cold Vapor (CV) mercury analyses with a digestion were performed on samples of the SRAT products. The data indicated that the DWPF SRAT processing limit was met. The limit is 0.45 $\mathrm{wt} \%$ on a total solids basis, and results were 0.35 wt\% for run SB4-19 and 0.237 wt\% for run SB4-20. Mercury collected as beads in either the SRAT condenser to MWWT transfer line or the MWWT itself during the runs. 
Duplicate rheological analyses were performed on the SRAT products and on the SME product, as well as on the solids and waste loading adjusted SME products. Attachment A presents the flow curves for the samples (see Figure A - 1 through Figure A - 3). The average Bingham Plastic yield stress and plastic viscosity using the Bingham Plastic rheological model are presented in Table 3-11.

Table 3-11: Rheological Data on SRAT Products and SME Samples

\begin{tabular}{||l|c|c||}
\hline \hline Sample & $\begin{array}{c}\text { Yield Stress } \\
\left(\text { dynes/cm }^{2}\right)\end{array}$ & Consistency (cP) \\
\hline SB4-19 Product & 64.6 & 12.97 \\
\hline SB4-20 Product & 7.5 & 7.28 \\
\hline SME Product (43\% WL and 50\% TS) & 1214 & 138.9 \\
\hline Adjusted SME Product (43\% WL and 45\% TS) & 516 & 94.5 \\
\hline Adjusted SME Product (35\% WL and 50\% TS) & 646 & 111.2 \\
\hline Adjusted SME Product (35\% WL and 45\% TS) & 320 & 59.1 \\
\hline
\end{tabular}

WL-Waste Loading and TS - Total Solids

The SRAT products were visually and rheologically thin, and were much thinner than the starting sludge (i.e., 300 dynes $/ \mathrm{cm}^{2}$ and $15 \mathrm{cP}$ ). During characterization, they were ramped from 0 to $600 / \mathrm{s}$ shear rate. For the SB4-19 product (see Figure A - 1), the up flow curve was above the down flow curve. The Bingham Plastic model was fitted to the down flow curve, since the down flow curves were more nearly linear. For the SB4-20 product (see Figure A - 1), the up and down flow curves overlaid, but the model was also fitted to the down curve. The SB4-19 product yield stress is within the nominal DWPF operating window and is similar to the yield stress measured for other SRAT products, but the consistency was slightly higher (Koopman 2004). For the SB4-20 product, the yield stress is below the nominal DWPF operating range but is consistent with some of the SRAT products tested during SB3 qualification, while the consistency was within the nominal range (Koopman 2004).

As mentioned above, all of the SME products were very thick. The parallel plate geometry was used to measure the rheology of the samples. Characterization involved ramping from 0 to 300/s shear rate. The up and down flow curves for the $43 \%$ waste loading/50\% total solids sample were very similar (see Figure A 2 ) and the model was fitted to the up curve. The down curve was higher than the up curve for the $43 \%$ waste loading $/ 45 \%$ total solids sample but the model was also fitted to the up curve for consistency between the samples. A large difference in yield stress is evident between the two samples (see Figure A - 2). The samples at 35\% waste loading were fitted on a different plot (see Figure A - 3) and exhibited similar behavior. The $35 \%$ waste loading $/ 50 \%$ total solids sample down flow curve was higher than the up flow curve with the model fitted to the more conservative up flow curve. The $35 \%$ waste loading/45\% total solids sample exhibited the same behavior. None of these products were considered acceptable for the SMRF. The yield stress of the SME samples were also higher than other previously measured DWPF simulant and actual sludge samples, but the trends exhibited for waste loading and total solids loading were consistent with earlier studies (Koopman 2004). Therefore, if the simulants are representative of the actual SB4 SME products, then problems with pumping and mixing may be expected. 


\subsection{CONCLUSIONS}

The Phase I SRAT runs with co-precipitated SB4 simulant without Tank 4 have been completed. The runs examined the SB4 1.6M Na wash endpoint and assumed blending with a 40" heel of SB3. Noble metals at the projected maximum case and mercury at what is believed to be a conservative low value from a hydrogen perspective were used in the run to bound the acid addition window. Both SRAT runs met nitrite destruction, hydrogen generation, manganese reduction, and mercury reduction objectives. The lower acid stoichiometry tested easily met the nitrite destruction limit with nitrite completely destroyed 6 hours into reflux. The upper acid tested was $170 \%$ acid stoichiometry. Hydrogen was less than half of the DWPF limit in the SRAT. Although a SME cycle was not performed directly with the $170 \%$ acid case, the data indicate that an acid operating window of $\sim 40 \%$ stoichiometry is feasible at this wash endpoint. This could also be accomplished by slightly decreasing the acid used at the lower end if need be. Information on the expected formate destruction and nitrite to nitrate conversion was gained and was fairly consistent between the runs. The sludge was very thick at the start of processing. After about a third of the formic acid was added, the sludge was visually thinner. No significant processing problems such as foaming, loss of heat transfer, or air entrainment were seen with this simulant.

Compared to previous testing with SB4 simulant, this sludge appeared to behave more typical of other sludge batches. At this point, the exact cause for the change in chemistry is not well understood but is being investigated in the ITS Simulant Development program.

Profiles of the $\mathrm{pH}$ during SRAT processing could not be obtained due to the thickness of the sludge. The SRAT product processed at the lower acid had a $\mathrm{pH}$ of $\sim 7.5$, while the higher acid run produced a SRAT product with a $\mathrm{pH}$ of $\sim 5.2$. The combined SME product had a $\mathrm{pH}$ of $\sim 6.1$ after cooling. During the SME cycle, the $\mathrm{pH}$ increased steadily from slightly below 5 to around 5.4. The lower pH SRAT product showed increased solubility for several elements, including $\mathrm{Mn}$, as would be expected.

As with previous runs, the peak $\mathrm{CO}_{2}$ concentrations were seen during acid addition and were attributed to carbonate destruction and nitrite destruction. The peak $\mathrm{N}_{2} \mathrm{O}$ and $\mathrm{NO}$ generation rate were found to depend on acid addition amount. 
WSRC-TR-2005-00493

Revision 0

This page intentionally left blank. 


\subsection{RECOMMENDATIONS/PATH FORWARD}

Due to the thick nature of the simulant prepared for this testing and the current problems with settling of Tank 51, flowsheet testing will be put on hold until the second quarter of the fiscal year. This will allow the Closure Business Unit to develop a plan for sludge washing to meet the target readiness date. It will also allow the ITS Simulant Development program an opportunity to understand the differences in the sludge preparation techniques to attempt to make a more prototypical sludge simulant.

In the second quarter, the testing will focus on developing the processing strategy for the qualification run on SB4 only in the Shielded Cells and on processing with a heel of SB3 in the DWPF. Future testing will include testing at the projected $\mathrm{Hg}$ concentrations since studies indicate a significant impact on hydrogen generation. The testing objective will be to ensure that complete mercury reduction to the DWPF limit is practical with the current DWPF operating strategy. As new noble metals information is obtained, the numbers and levels will be incorporated in testing to reduce the conservatism in the operating window. Lessons learned from the ITS Hydrogen Program will also be incorporated. 
WSRC-TR-2005-00493

Revision 0

This page intentionally left blank. 


\subsection{REFERENCES}

Baich, M.A., Task Technical \& QA Plan: Sludge Batch 4 Simulant Flowsheet Studies with MCU and ARP, WSRC-RP-2004-00881, Savannah River Site, Aiken, SC 29808 (2004).

Baich, M.A., Analytical Study Plan for Sludge Batch 4 with ARP and MCU Flowsheet Studies using Simulants, SRNL-GPD-2005-00001, Savannah River Site, Aiken, SC 29808 (2005).

Baich, M.A., C.C. Herman, D.R. Best, M.F. Williams, and E.K. Hansen, Sludge Batch 4 Initial Simulant Flowsheet Studies: Phase I SRAT Results, WSRC-TR-2005-00194, Savannah River Site, Aiken, SC 29808 (2005).

Bannochie, C.J., and T.L. Fellinger, Tank 11H Analytical Results as Input to DWPF Sludge Batch 4, WSRCTR-2004-00473, Savannah River Site, Aiken, SC 29808 (2004).

Bannochie, C.J., J.M. Pareizs, and D.C. Koopman, Sludge Batch 2/3 Blend SRAT Cycle in the SRNL Shielded Cells, WSRC-TR-2004-00097, Savannah River Site, Aiken, SC 29808 (2004).

Bibler, N.E., Prediction of Noble Metal Concentrations in Sludge Batch 4, SRNL-ITB-2005-00001, Savannah River Site, Aiken, SC 29808 (2005).

Elder, H.H., Estimate of Sludge Batch 4 Calcine Composition, CBU-PIT-2005-00134, Savannah River Site, Aiken, SC 29808 (2005a).

Elder, H.H., Estimate of Sludge Batch 4 Calcine Composition Additional Cases, CBU-PIT-2005-00176, Savannah River Site, Aiken, SC 29808 (2005b).

Herman, C.C., Lab-Scale CPC Equipment Set-up, SRNL-ITS-2005-00129, Savannah River Site, Aiken, SC $29808(2005 a)$.

Herman, C.C., SB4-19 Run Plan: 1.6M NaSB4 Wash Endpoint with 40” SB3 Heel - Low Acid, SRNL-ITS2005-00210, Savannah River Site, Aiken, SC 29808 (2005b).

Herman, C.C., SB4-20 Run Plan: 1.6M NaSB4 Wash Endpoint with 40” SB3 Heel - High Acid, SRNL-ITS2005-00211, Savannah River Site, Aiken, SC 29808 (2005c).

Herman, D.T., M.E. Stone, and M.R. Poirier, Preparation of Sludge Batch 4 Simulant, SRNL-WPT-200500130, Savannah River Site, Aiken, SC 29808 (2005).

Herman, C.C., D.C. Koopman, D.R. Best, T.K. Snyder, and M.F. Williams, Sludge Batch 3 Simulant Flowsheet Studies: Final Phase SRAT/SME Result, WSRC-TR-2003-00422, Savannah River Site, Aiken, SC 29808 (2003).

Hsu, C.W., Formic Acid Requirement in the DWPF Chemical Processing Cell, WSRC-RP-90-0554, Savannah River Site, Aiken, SC 29808 (1990).

Jantzen, C.M., J.R. Zamecnik, D.C. Koopman, C.C. Herman, and J.B. Pickett, Electron Equivalents Model for Controlling Reduction-Oxidation (Redox) Equilibrium during High Level Waste (HLW) Vitrification, WSRC-TR-2003-00126, Savannah River Site, Aiken, SC 29808 (2003). 
Koopman, D.C., A Comparison of Rheology Data for Radioactive and Simulant Savannah River Site Waste, WSRC-TR-2004-00044, Savannah River Site, Aiken, SC 29808 (2004).

Koopman, D.C., DWPF Hydrogen Generation Study - Form of Noble Metal SRAT Testing, WSRC-TR2005-00286, Savannah River Site, Aiken, SC 29808 (2005).

Stone, M.E., 2.5L SME Test. SRNL-ITS-2005-00215, Savannah River Site, Aiken, SC 29808 (2005a).

Stone, M.E., Run Plan for Rheology Measurements for 05-SB4-0235/0236. SRNL-ITS-2005-00218, Savannah River Site, Aiken, SC 29808 (2005b).

Washburn, F.A., Sludge Batch 4 Flowsheet Studies. HLW/DWPF/TTR-04-0031, Savannah River Site, Aiken, SC 29808 (2004). 


\subsection{ACKNOWLEDGMENTS}

The authors would like to acknowledge the following personnel and groups for their assistance in performing the studies and analyzing the required samples:

- R E. Eibling for preparing simulant recipe calculations.

- D.T. Herman, J.G. Wheeler, V.L. Bush, and S.A. Hatcher for assistance with and preparing the sludge simulant.

- D.P. Healy, T.O. Burckhalter, J.W. Duvall, I.A. Reamer, V.J. Williams, and R.J. Workman for performing the SRAT runs and assisting with sample analysis.

- P.A. Toole for providing assistance with the analyses.

- J.M. Pareizs for assistance with calibration and running the gas chromatographs during the runs.

- E.K. Hansen for providing rheology analysis. 
WSRC-TR-2005-00493

Revision 0

This page intentionally left blank. 
WSRC-TR-2005-00493

Revision 0

\section{ATTACHMENT A. RUN PARAMETERS AND SUPPORTING DATA}


Table A - 1: SRAT Run Parameters

\begin{tabular}{|c|c|c|}
\hline Parameter & SB4-19 & SB4-20 \\
\hline Initial Sludge Mass (g) & 2700 & 2700 \\
\hline Hg Target (wt\% in total solids) & 1.0 & 1.0 \\
\hline HgO Added (g) & 5.191 & 5.189 \\
\hline $\mathrm{AgNO}_{3}$ Added (g) & 0.0018 & 0.0018 \\
\hline $\mathrm{Pd}\left(\mathrm{NO}_{3}\right)_{2} * \mathrm{H}_{2} \mathrm{O}$ Added $(\mathrm{g})-15.27 \%$ Solution & 0.378 & 0.380 \\
\hline $\mathrm{Rh}\left(\mathrm{NO}_{3}\right)_{3} * 2 \mathrm{H}_{2} \mathrm{O}$ Added $(\mathrm{g})-4.93 \%$ Solution & 2.142 & 2.143 \\
\hline $\mathrm{RuCl}_{3}$ Added (d) & 0.932 & 0.933 \\
\hline Rinse Water for Trim Chemicals (g) & 140.0 & 140.0 \\
\hline DWPF SRAT Scale Factor $(6,000$ gallon basis $)$ & 9243 & 9213 \\
\hline Acid Stoichiometry & $129.4 \%$ & $169.7 \%$ \\
\hline Nitric Acid Amount Added (ml) & 28.979 & 55.274 \\
\hline Nitric Acid Addition Rate (ml/min) & 0.77 & 0.78 \\
\hline Nitric Acid Moles & 0.306 & 0.584 \\
\hline Formic Acid Amount Added (ml) & 149.078 & 188.531 \\
\hline Formic Acid Addition Rate (ml/min) & 0.78 & 0.79 \\
\hline Formic Acid Moles & 3.529 & 4.463 \\
\hline Total SRAT Dewater Amount (g) & 340.56 & 427.4 \\
\hline Concentration/Dewater Time after Boiling (hrs) & 1.78 & 2.5 \\
\hline SRAT Target Boil-up Rate (g/min) & 3.9 & 3.95 \\
\hline SRAT Air Purge on System (slm) & 673 & 678 \\
\hline SRAT Helium Purge on System (sccm) & 3.4 & 3.4 \\
\hline Initial Sludge pH with Trim Chemicals & 11.57 & 11.62 \\
\hline Antifoam Addition (g) & 38.00 & 38.24 \\
\hline Run Plan Document Number & $\begin{array}{l}\text { SRNL-ITS- } \\
2005--0210\end{array}$ & $\begin{array}{l}\text { SRNL-ITS } \\
2005--0211\end{array}$ \\
\hline
\end{tabular}

Table A - 2: SME Run Parameters

\begin{tabular}{|c|c|}
\hline Parameter & Value \\
\hline Total Frit Added (g) & 528.6 \\
\hline Total Formic Added (g) & 8.38 \\
\hline Total Water Added (g) & 494.76 \\
\hline Total Dewater during SME (g) & 1680.14 \\
\hline DWPF SME Scale Factor $(6,000$ gallon basis) & 8587 \\
\hline First Dewater Mass (g)/Time (min) & $265.14 \mathrm{~g} / 87 \mathrm{~min}$ \\
\hline Final Dewater Time (min) & $1376.52 \mathrm{~g} / 331 \mathrm{~min}$ \\
\hline SME Target Boil-up Rate (g/min) & 4.1 \\
\hline SME Air Purge on System (sccm) & 216 \\
\hline SME Helium Purge on System (sccm) & 1.08 \\
\hline pH at End of SME (at boiling) & 5.40 \\
\hline Antifoam Addition (g) & 5.43 \\
\hline Run Plan Document Number & SRNL-GPD-2005-00215 \\
\hline
\end{tabular}


WSRC-TR-2005-00493

Revision 0

Table A - 3: Mass Balance for Run SB4-19

\begin{tabular}{|l|c|c|c|c|}
\hline SB4-19 SRAT Run & Time & $\begin{array}{c}\text { Mass Change/ } \\
\text { Sample Wt }\end{array}$ & Comments & Running Mass \\
\hline Sludge & & 2700 & & 2700.00 \\
\hline Noble Metals & & 8.6448 & & 2708.64 \\
\hline Flush Water & & 140 & & 2848.64 \\
\hline Added 1:10 Antifoam \& Water & $6: 31$ & 10.86 & 5.43 g of each & 2859.50 \\
\hline Pre Nitric (05-SB4-211) & $7: 07$ & 12.04 & & 2847.46 \\
\hline Pre Nitric (05-SB4-212) & $7: 04$ & 10.62 & 4.36 supernate & 2836.84 \\
\hline Started Nitric Acid & $7: 26$ & & & 2874.92 \\
\hline Stopped Nitric Acid & $8: 04$ & 38.078 & 28.979 ml & 2863.56 \\
\hline Post Nitric (05-SB4-213) & $8: 15$ & 11.36 & & 2850.56 \\
\hline Post Nitric (05-SB4-214) & $8: 17$ & 13.00 & 5.4 supernate & \\
\hline Started Formic Acid & $8: 39$ & & & 3030.36 \\
\hline Finished Formic Acid & $11: 53$ & 179.8 & 149.078 ml & 3018.10 \\
\hline Post Formic (05-SB4-215) & $12: 03$ & 12.26 & & 3004.23 \\
\hline Post Formic (05-SB4-216) & $12: 04$ & 13.87 & 6.68 supernate & \\
\hline Added 1:10 Antifoam \& Water & $12: 08$ & 27.14 & 13.57 g of each & \\
\hline Boiling Started & $12: 20$ & & & 2690.81 \\
\hline Dewater finished & $14: 07$ & 340.56 & & 2676.82 \\
\hline 6 hr reflux (05-SB4-218) & $20: 07$ & 13.99 & & \\
\hline 6 hr reflux (05-SB4-219) & $20: 07$ & 14.45 & 5.87 supernate & \\
\hline \multicolumn{1}{|c|}{ SRAT complete } & $2: 07$ & & & \\
\hline Rheology sample & & 97.49 & & \\
\hline SRAT-Product-ML & & 124.12 & & \\
\hline SRAT-Product-Hg & & 21.24 & & \\
\hline Remaining SRAT & & 2354.7 & & \\
\hline & & 2597.55 & Delta & \\
\hline SRAT Product mass & & 48.13 & & \\
\hline FAVC collected & & 19.23 & With offgas Delta & \\
\hline MWWT initial & & 48.04 & & \\
\hline
\end{tabular}


WSRC-TR-2005-00493

Revision 0

Table A - 4: Mass Balance for Run SB4-20

\begin{tabular}{|l|c|c|l|c|}
\hline SB4-20 SRAT Cycle & Time & $\begin{array}{c}\text { Mass Change/ } \\
\text { Sample Wt }\end{array}$ & Comments & Running Mass \\
\hline Sludge & & 2700 & & 2700.00 \\
\hline Noble Metals & & 8.6468 & & 2708.65 \\
\hline Flush Water & & 140 & & 2848.65 \\
\hline Added 1:10 Antifoam \& Water & $6: 34$ & 10.92 & 5.46 g of each & 2859.57 \\
\hline Pre Nitric (05-SB4-225) & $7: 19$ & 13.59 & 5.1493 supernate & 2845.98 \\
\hline Started Nitric Acid & $7: 53$ & & & 2918.61 \\
\hline Stopped Nitric Acid & $9: 05$ & 72.630 & $55.274 \mathrm{ml}$ & 2904.09 \\
\hline Post Nitric (05-SB4-226) & $9: 09$ & 14.52 & & 3131.49 \\
\hline Started Formic Acid & $9: 14$ & & & 3116.83 \\
\hline Finished Formic Acid & $13: 17$ & 227.4 & 188.531 ml & 3144.15 \\
\hline Post Formic (05-SB4-227) & $13: 21$ & 14.66 & 7.39 supernate & \\
\hline Added 1:10 Antifoam \& Water & $13: 24$ & 27.32 & 13.66 g of each & 2716.75 \\
\hline Boiling Started & $13: 35$ & & & \\
\hline Dewater finished & $16: 05$ & 427.4 & & \\
\hline 6 hr reflux (05-SB4-229) & $22: 05$ & 16.64 & 7.5 supernate & \\
\hline \multicolumn{1}{|c|}{ SRAT complete } & $4: 05$ & & & \\
\hline Rheology sample & & 127.8 & & \\
\hline SRAT-Product-ML & & 149.96 & & \\
\hline SRAT-Product-Hg & & 35.74 & & \\
\hline Remaining SRAT & & 2213.4 & & \\
\hline \multicolumn{1}{|c|}{ SRAT Product mass } & & 2526.9 & Delta & \\
\hline MWWT final & & 49.26 & & With offgas Delta \\
\hline FAVC collected & & 25.11 & & \\
\hline MWWT initial & & 50.55 & & \\
\hline
\end{tabular}

Table A - 5: SME Cycle Mass Balance

\begin{tabular}{|l|c|c|c|c|}
\hline SME Cycle & Time & $\begin{array}{c}\text { Mass Change/ } \\
\text { Sample Wt }\end{array}$ & Comments & Running Mass \\
\hline SB4-19 product & $16: 07$ & 1500 & & 1500 \\
\hline SB4-20 product & $16: 07$ & 1500 & & 3000 \\
\hline First frit addition & $16: 07$ & 264.3 & & 3264.3 \\
\hline Formic acid & $16: 07$ & 4.41 & & 3268.71 \\
\hline Frit water & $16: 07$ & 259.92 & & 3528.63 \\
\hline Added 1:10 Antifoam \& Water & $6: 12$ & 10.86 & 5.43 of each & 3539.49 \\
\hline At boiling & $6: 53$ & & & \\
\hline 1st dewater complete & $8: 20$ & 265.14 & & 3274.35 \\
\hline Second frit addition & $8: 35$ & 264.32 & & 3538.67 \\
\hline Formic acid & $8: 35$ & 4.41 & & 3543.08 \\
\hline Frit water & $8: 35$ & 259.92 & & 3803 \\
\hline At boiling & $8: 52$ & & & \\
\hline 2nd dewater complete & $9: 50$ & 301.52 & & 3501.48 \\
\hline Final dewater & $14: 23$ & 1075 & & 2426.48 \\
\hline Turned heat off & $14: 23$ & & & \\
\hline \multicolumn{2}{|l|}{} & 2317.1 & & Delta \\
\hline
\end{tabular}


WSRC-TR-2005-00493

Revision 0

Figure A - 1: Flow Curves for SRAT Products

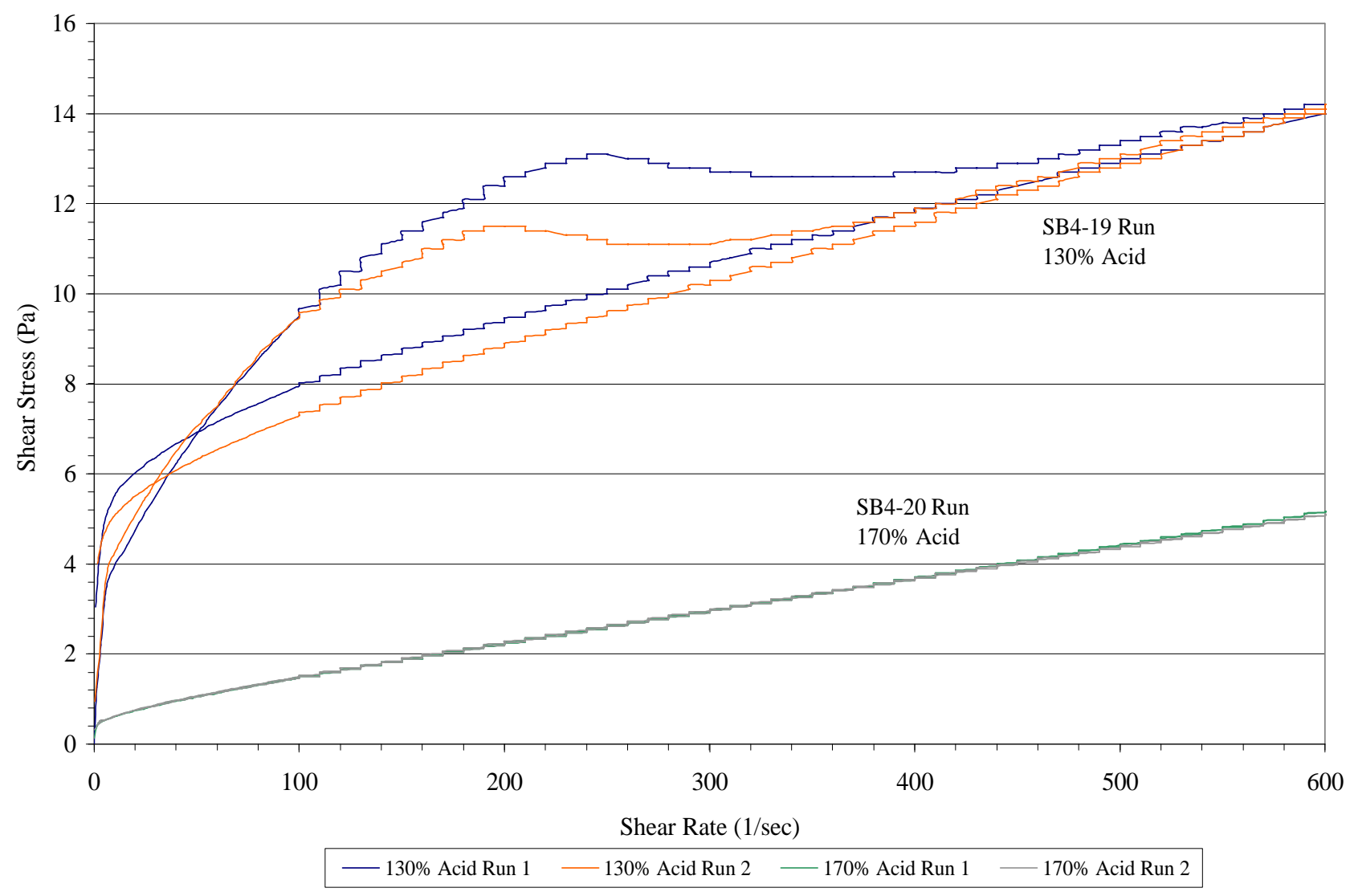


Figure A - 2: Flow Curves for SME Product at $43 \%$ Waste Loading

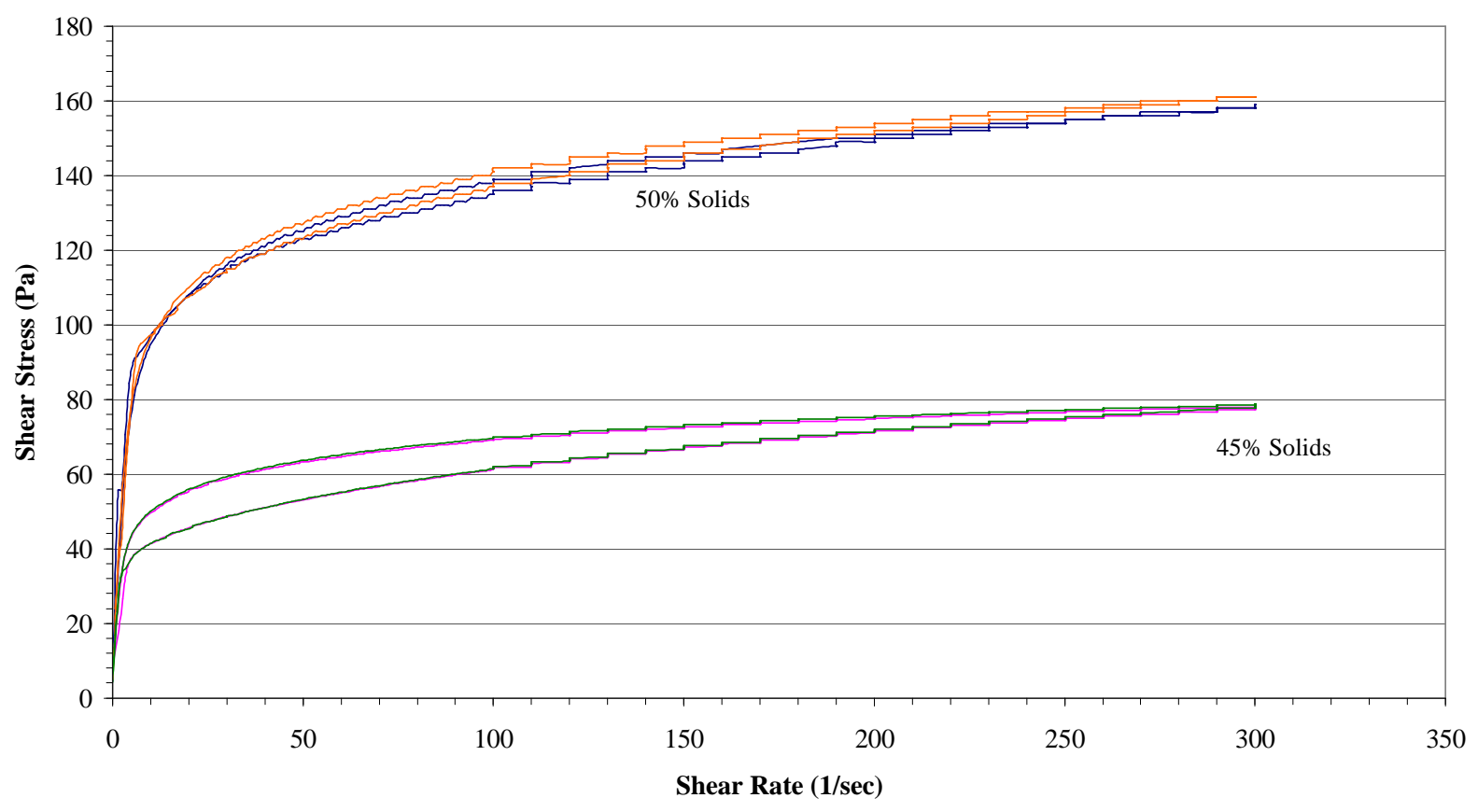

- 43\% WL 50\% Solids Run $1-43 \%$ WL 50\% Solids Run $2-43 \%$ WL $45 \%$ Solids Run $1-43 \%$ WL $45 \%$ Solids Run 2

Figure A - 3: Flow Curves for SME Product at 35\% Waste Loading

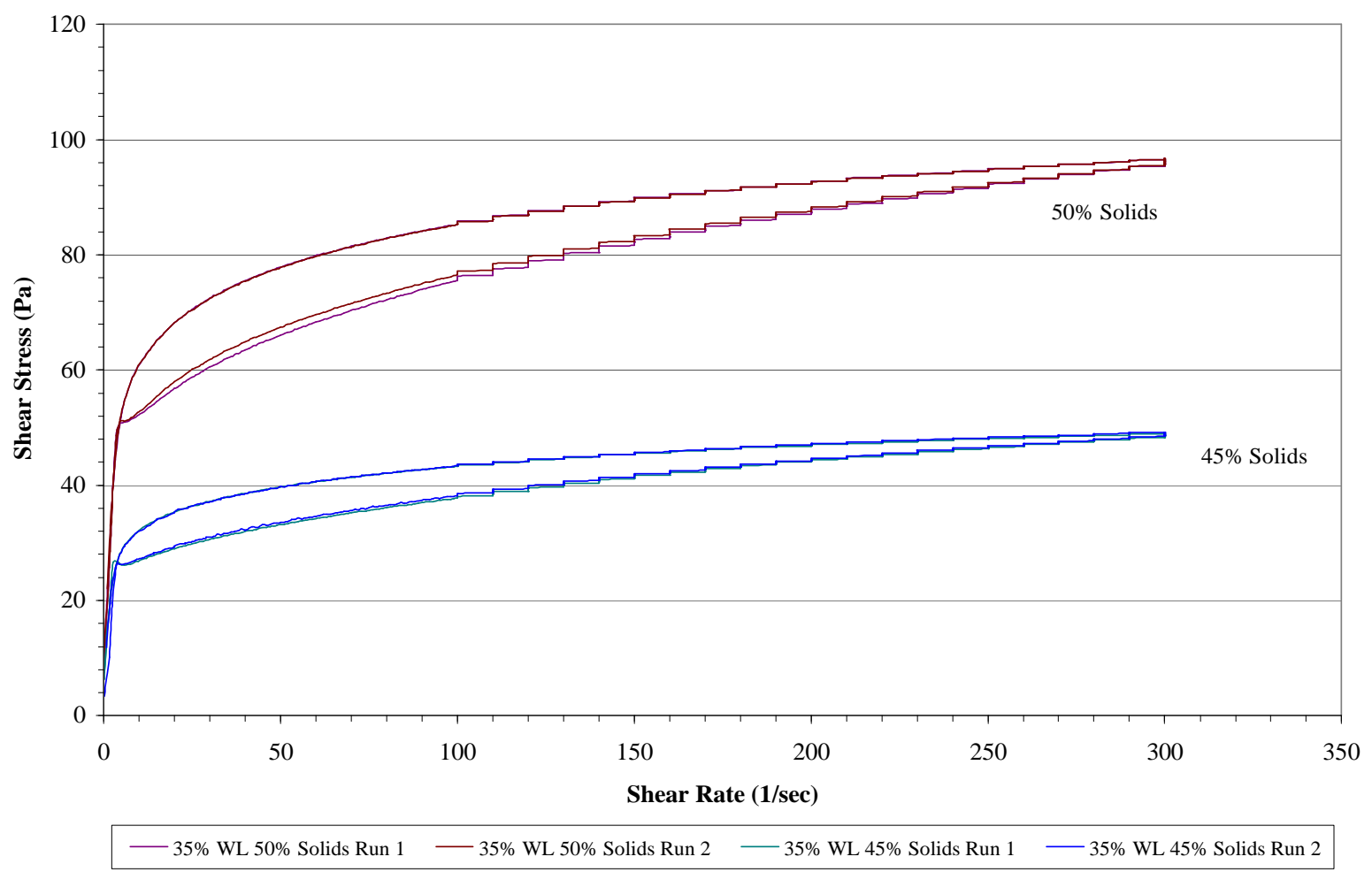


Distribution:

M. A. Barnes, 999-W

C. J. Bannochie, 773-42A

D. R. Best, 786-1A

N. E. Bibler, SRNL

T. B. Calloway, 999-W

D. A. Crowley, SRNL

B. A. Davis, 704-27S

R. E. Edwards, SRNL

R. E. Eibling, 999-W

H. H. Elder, 766-H

T. L. Fellinger, SRNL

J. M. Gillam, 766-H

J. R. Harbour, 773-42A

C. C. Herman, 773-42A

P. J. Hill, 766-H

R. M. Hoeppel, 704-27S

J. F. Iaukea, 704-30S

C. M. Jantzen, SRNL

D. C. Koopman, 773-42A

D. P. Lambert, 999-W

S. L. Marra, 999-W

M. S. Miller, 704-S

J. E. Occhipinti, 704-S

J. M. Pareizs, SRNL

D. K. Peeler, 999-W

J. W. Ray, 704-S

M. A. Rios-Armstrong, 766-H

H. B. Shah, 766-H

M. E. Stone, 999-W

W. B. Van-Pelt, 704-S

J. P. Vaughan, 773-41A

G. G. Wicks, SRNL

M. F. Williams, 999-1W 